\title{
A Multidisciplinary Approach on the Perioperative Antithrombotic Management of Patients With Coronary Stents Undergoing Surgery

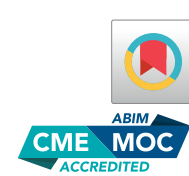

\section{Surgery After Stenting 2}

Roberta Rossini, MD, PHD, ${ }^{a}$ Giuseppe Tarantini, MD, $\mathrm{PHD},{ }^{\mathrm{b}}$ Giuseppe Musumeci, MD, ${ }^{\mathrm{a}}$ Giulia Masiero, MD, ${ }^{\mathrm{b}}$ Emanuele Barbato, MD, ${ }^{\mathrm{c}}$ Paolo Calabrò, MD, ${ }^{\mathrm{d}}$ Davide Capodanno, MD, $\mathrm{PHD},{ }^{\mathrm{e}, \mathrm{f}}$ Sergio Leonardi, MD, ${ }^{\mathrm{g}}$ Maddalena Lettino, MD, ${ }^{\mathrm{h}}$ Ugo Limbruno, MD, ${ }^{\mathrm{i}}$ Alberto Menozzi, MD, PHD, ${ }^{\mathrm{j}}$ U.O. Alfredo Marchese, MD, ${ }^{\mathrm{k}}$ Francesco Saia, MD, $\mathrm{PHD},{ }^{\mathrm{l}}$ Marco Valgimigli, MD, ${ }^{\mathrm{m}}$ Walter Ageno, MD, ${ }^{\mathrm{n}}$ Anna Falanga, MD, ${ }^{\circ}$ Antonio Corcione, $\mathrm{MD},{ }^{\mathrm{p}}$ Alessandro Locatelli, MD, ${ }^{\mathrm{a}}$ Marco Montorsi, MD, ${ }^{\mathrm{q}}$ Diego Piazza, MD, ${ }^{\mathrm{r}}$ Andrea Stella, MD, ${ }^{\mathrm{s}}$ Antonio Bozzani, MD, Alessandro Parolari, MD, ${ }^{\mathrm{u}}$ Roberto Carone, $\mathrm{MD},{ }^{\mathrm{v}}$ Dominick J. Angiolillo, MD, $\mathrm{PHD},{ }^{\mathrm{w}}$ on behalf of the Italian Society of Interventional Cardiology (SICI-GISE), Italian Society for the Study of Haemostasis and Thrombosis (SISET), Italian Society of Anesthesia and Intensive Care Medicine (SIAARTI), Italian Society of Surgery (SIC), Italian Society for Cardiac Surgery (SICCH), Italian Society of Vascular and Endovascular Surgery (SICVE), Italian Society of Urology (SIU), Italian Orthopaedic Society (SIOT), Italian Society of Thoracic Surgeons (SICT), Italian Federation of Scientific Societies of Digestive System Diseases (FISMAD), Italian Society of Digestive Endoscopy (SIED), Italian Association of Hospital Gastroenterology and Digestive Endoscopy (AIGO), Italian Association of Gastroenterology and Digestive Endoscopy (SIGE), Italian Society of Maxillofacial Surgery (SICMF), Italian Society of Reconstructive Plastic Surgery and Aesthetics (SICPRE), Italian Society of Gynecology and Obstetrics (SIGO), Italian Society of Neurosurgery (SINch), Italian Association of Hospital Pulmonologist (AIPO), Italian Society of Periodontology (SIdP), Italian Society of Ophthalmology (SOI), Italian Association of Hospital Otorhinolaryngologist (AOOI), Italian Association of Hospital Surgeons (ACOI), Association of Obstetricians Gynecologists Italian Hospital (AOGOI)

\section{JACC: CARDIOVASCULAR INTERVENTIONS CME/MOC}

This article has been selected as this issue's CME/MOC activity, available online at http://www.acc.org/jacc-journals-cme by selecting the JACC Journals CME/MOC tab.

\section{Accreditation and Designation Statement}

The American College of Cardiology Foundation (ACCF) is accredited by the Accreditation Council for Continuing Medical Education (ACCME) to provide continuing medical education for physicians.

The ACCF designates this Journal-based CME/MOC activity for a maximum of 1 AMA PRA Category 1 Credit(s). Physicians should only claim credit commensurate with the extent of their participation in the activity.

Method of Participation and Receipt of CME/MOC Certificate

To obtain credit for this CME/MOC activity, you must:

1. Be an ACC member or JACC: Cardiovascular Interventions subscriber.

2. Carefully read the CME/MOC-designated article available online and in this issue of the journal.
3. Answer the post-test questions. At least 2 out of the 3 questions provided must be answered correctly to obtain CME/MOC credit.

4. Complete a brief evaluation.

5. Claim your CME/MOC credit and receive your certificate electronically by following the instructions given at the conclusion of the activity.

CME/MOC Objective for This Article: At the end of the activity the reader should be able to: 1) recognize the bleeding risk associated with the vast majority of surgical and endoscopic interventions; 2) appraise the ischemic risk of patients with prior coronary stenting who undergo cardiac and noncardiac surgery; and 3) identify the optimal bridge therapy with cangrelor.

CME/MOC Editor Disclosure: JACC: Cardiovascular Interventions CME/MOC Editor Bill Gogas, MD, PhD, has reported that he has no disclosures.

Author Disclosures: Dr. Rossini has received consulting fees or honoraria from Eli Lilly and Co., Daiichi Sankyo, AstraZeneca, Bayer, and Pfizer. Dr. Tarantini has received lecture honoraria from Boston Scientific, St. Jude Medical, Philips Volcano, Medtronic, and Abbott Vascular. Dr. Musumeci has received lecture honoraria from Eli Lilly and Co., Daiichi Sankyo, AstraZeneca, Chiesi, St. Jude Medical, and Abbott Vascular. Dr. Capodanno 
has received lecture and/or consulting honoraria from AstraZeneca and Bayer. Dr. Leonardi has served on the advisory board for Chiesi, The Medicines Company, and AstraZeneca. Dr. Lettino has received speaker fees from and has served on the advisory board for AstraZeneca, Bayer Boehringer Ingelheim, Daiichi Sankyo, Eli Lilly and Co. The Medicines Company, Bristol-Myers Squibb, Merck Sharp \& Dohme, and Pfizer. Dr. Menozzi has received lecture and/or consulting honoraria from Abbott Vascular, AstraZeneca, Bayer, Boehringer Ingelheim, Chiesi, Daiichi Sankyo, and The Medicines Company. Dr. Saia has served on the advisory board for AstraZeneca, Daiichi Sankyo, Bayer, Medtronic, Abbott Vascular, and St. Jude Medical; and has served as a lecturer for AstraZeneca, Daiich Sankyo, Bayer, Medtronic, Abbott Vascular, St. Jude Medical, LivaNova, Servier, Menarini, Edwards Lifesciences, Boston Scientific, and Terumo. Dr. Ageno has received speaker honoraria from and participated in scientific advisory boards for Boehringer Ingelheim, Bayer, Bristol-Myers Squibb/Pfizer, Daiichi Sankyo, Aspen, Stago, CSL Behring, and Portola; and has received research support from Bayer. Dr. Angiolillo has received consulting fees or honoraria from Amgen, Aralez, AstraZeneca, Bayer, Biosensors, Bristol-Myers Squibb, Chiesi, Daiichi Sankyo, Eli Lilly and Co.,
Janssen, Merck, PLx Pharma, Pfizer, Sanofi, and The Medicines Company; participated in review activities from CeloNova and St. Jude Medical; received institutional payments for grants from Amgen, AstraZeneca, Bayer, Biosensors, CeloNova, CSL Behring, Daiichi Sankyo, Eisai, Eli Lilly and Co. Gilead, Janssen, Matsutani Chemical Industry Co., Merck, Novartis, Osprey Medical, and Renal Guard Solutions; and received funding from the Scott R. MacKenzie Foundation and the National Institutes of Health/National Center for Advancing Translational Sciences Clinical and Translational Science Award to the University of Florida UL1 TRoooo64 and National Institutes of Health/National Human Genome Research Institute U01 HG007269. All other authors have reported that they have no relationships relevant to the contents of this paper to disclose.

Medium of Participation: Print (article only); online (article and quiz).

\section{CME/MOC Term of Approval}

Issue Date: March 12, 2018

Expiration Date: March 11, 2019

From the a Dipartimento Emergenze e Aree Critiche, Ospedale Santa Croce e Carle, Cuneo, Italy; ${ }^{\mathrm{b}}$ Department of Cardiac, Thoracic and Vascular Sciences, University of Padua Medical School, Padua, Italy; 'Division of Cardiology, Department of Advanced Biomedical Sciences, Federico II University, Naples, Italy; ${ }^{\mathrm{d} D i v i s i o n}$ of Cardiology, Department of Cardio-Thoracic Sciences, Università degli Studi della Campania "Luigi Vanvitelli," Naples, Italy; 'Division of Cardiology, Cardio-Thoracic-Vascular Department, Azienda Ospedaliero Universitaria "Policlinico-Vittorio Emanuele, Catania, Italy; ${ }^{\mathrm{f} D e p a r t m e n t}$ of General Surgery and Medical-Surgical Specialties, University of Catania, Catania, Italy; ${ }^{\mathrm{g}}$ Coronary Care Unit, Fondazione IRCCS Policlinico San

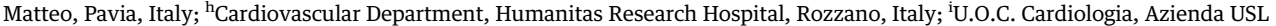
Toscana Sudest, Grosseto, Italy; ${ }^{j}$ Unità Operativa di Cardiologia, Azienda Ospedaliero-Universitaria di Parma, Italy; ${ }^{k}$ U.O.C. Cardiologia Interventistica, Anthea Hospital, GVM Care \& Research, Bari, Italy; ${ }^{1}$ Cardiology Unit, Cardio-Thoraco-Vascular Department, University Hospital of Bologna, Policlinico S. Orsola-Malpighi, Bologna, Italy; ${ }^{\mathrm{m}}$ Swiss Cardiovascular Centre Bern, Bern University Hospital, Bern, Switzerland; ${ }^{\mathrm{n}}$ Degenza Breve Internistica e Centro Trombosi ed Emostasi, Dipartimento di Medicina e Chirurgia, Università dell'Insubria, Varese, Italy; ${ }^{\circ}$ Department of Immunohematology and Transfusion Medicine, Thrombosis and Hemostasis Center, ASST Papa Giovanni XXIII, Bergamo, Italy; ${ }^{\mathrm{P} D e p a r t m e n t ~ o f ~ A n a e s t h e s i a ~ a n d ~ C r i t i c a l ~ C a r e, ~ A O R N ~ D e i ~ C o l l i, ~}$ Naples, Italy; ${ }^{\mathrm{q}}$ Dipartimento di Chirurgia Generale, Humanitas Research Hospital and University, Milano, Italy; ${ }^{\mathrm{r}}$ Policlinico Vittorio

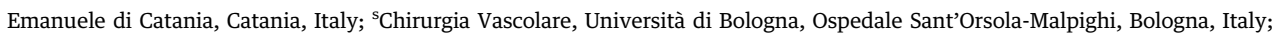
tUOC Chirurgia Vascolare, Dipartimento di Scienze Chirurgiche, Fondazione I.R.C.C.S. Policlinico San Matteo, Pavia, Italy; unipartimento di Scienze Biomediche per la Salute, Policlinico San Donato IRCCS, University of Milano, Milan, Italy; ${ }^{\mathrm{v}}$ Azienda Ospedaliera Universitaria Città della salute e della scienza, Torino, Italy; and the wDivision of Cardiology, University of Florida, College of Medicine-Jacksonville, Jacksonville, Florida. Dr. Rossini has received consulting fees or honoraria from Eli Lilly and Co., Daiichi Sankyo, AstraZeneca, Bayer, and Pfizer. Dr. Tarantini has received lecture honoraria from Boston Scientific, St. Jude Medical, Philips Volcano, Medtronic, and Abbott Vascular. Dr. Musumeci has received lecture honoraria from Eli Lilly and Co., Daiichi Sankyo, AstraZeneca, Chiesi, St. Jude Medical, and Abbott Vascular. Dr. Capodanno has received lecture and/or consulting honoraria from AstraZeneca and Bayer. Dr. Leonardi has served on the advisory board for Chiesi, The Medicines Company, and AstraZeneca. Dr. Lettino has received speaker fees from and has served on the advisory board for AstraZeneca, Bayer, Boehringer Ingelheim, Daiichi Sankyo, Eli Lilly and Co., The Medicines Company, Bristol-Myers Squibb, Merck Sharp \& Dohme, and Pfizer. Dr. Menozzi has received lecture and/or consulting honoraria from Abbott Vascular, AstraZeneca, Bayer, Boehringer Ingelheim, Chiesi, Daiichi Sankyo, and The Medicines Company. Dr. Saia has served on the advisory board for AstraZeneca, Daiichi Sankyo, Bayer, Medtronic, Abbott Vascular, and St. Jude Medical; and has served as a lecturer for AstraZeneca, Daiichi Sankyo, Bayer, Medtronic, Abbott Vascular, St. Jude Medical, LivaNova, Servier, Menarini, Edwards Lifesciences, Boston Scientific, and Terumo. Dr. Ageno has received speaker honoraria from and participated in scientific advisory boards for Boehringer Ingelheim, Bayer, Bristol-Myers Squibb/Pfizer, Daiichi Sankyo, Aspen, Stago, CSL Behring, Portola; and has received research support from Bayer. Dr. Angiolillo has received consulting fees or honoraria from Amgen, Aralez, AstraZeneca, Bayer, Biosensors, Bristol-Myers Squibb, Chiesi, Daiichi Sankyo, Eli Lilly and Co., Janssen, Merck, PLx Pharma, Pfizer, Sanofi, and The Medicines Company; participated in review activities from CeloNova and St. Jude Medical; received institutional payments for grants from Amgen, AstraZeneca, Bayer, Biosensors, CeloNova, CSL Behring, Daiichi Sankyo, Eisai, Eli Lilly and Co., Gilead, Janssen, Matsutani Chemical Industry Co., Merck, Novartis, Osprey Medical, and Renal Guard Solutions; and received funding from the Scott R. MacKenzie Foundation and the National Institutes of Health/National Center for Advancing Translational Sciences Clinical and Translational Science Award to the University of Florida UL1 TRoooo64 and National Institutes of Health/National Human Genome Research Institute U01 HGo07269. All other authors have reported that they have no relationships relevant to the contents of this paper to disclose. 


\section{A Multidisciplinary Approach on the Perioperative Antithrombotic Management of Patients With Coronary Stents Undergoing Surgery}

\section{Surgery After Stenting 2}

Roberta Rossini, MD, PHD, ${ }^{\text {a }}$ Giuseppe Tarantini, MD, $\mathrm{PHD},{ }^{\mathrm{b}}$ Giuseppe Musumeci, MD, ${ }^{\mathrm{a}}$ Giulia Masiero, MD, ${ }^{\mathrm{b}}$ Emanuele Barbato, MD, ${ }^{\mathrm{c}}$ Paolo Calabrò, MD, ${ }^{\mathrm{d}}$ Davide Capodanno, MD, PHD, ${ }^{\mathrm{e}, \mathrm{f}}$ Sergio Leonardi, MD, ${ }^{\mathrm{g}}$ Maddalena Lettino, MD, ${ }^{\mathrm{h}}$ Ugo Limbruno, MD, ${ }^{\mathrm{i}}$ Alberto Menozzi, MD, PHD, ${ }^{\mathrm{j}}$ U.O. Alfredo Marchese, MD, ${ }^{\mathrm{k}}$ Francesco Saia, MD, $\mathrm{PHD},{ }^{1}$ Marco Valgimigli, $\mathrm{MD},{ }^{\mathrm{m}}$ Walter Ageno, $\mathrm{MD},{ }^{\mathrm{n}}$ Anna Falanga, $\mathrm{MD},{ }^{\circ}$ Antonio Corcione, $\mathrm{MD},{ }^{\mathrm{p}}$ Alessandro Locatelli, MD, ${ }^{\mathrm{a}}$ Marco Montorsi, MD, ${ }^{\mathrm{q}}$ Diego Piazza, MD, ${ }^{\mathrm{r}}$ Andrea Stella, MD, ${ }^{\mathrm{s}}$ Antonio Bozzani, MD, ${ }^{\mathrm{t}}$ Alessandro Parolari, MD, ${ }^{\mathrm{u}}$ Roberto Carone, $\mathrm{MD},{ }^{\mathrm{v}}$ Dominick J. Angiolillo, MD, $\mathrm{PHD}^{\mathrm{w}}$ on behalf of the Italian Society of Interventional Cardiology (SICI-GISE), Italian Society for the Study of Haemostasis and Thrombosis (SISET), Italian Society of Anesthesia and Intensive Care Medicine (SIAARTI), Italian Society of Surgery (SIC), Italian Society for Cardiac Surgery (SICCH), Italian Society of Vascular and Endovascular Surgery (SICVE), Italian Society of Urology (SIU), Italian Orthopaedic Society (SIOT), Italian Society of Thoracic Surgeons (SICT), Italian Federation of Scientific Societies of Digestive System Diseases (FISMAD), Italian Society of Digestive Endoscopy (SIED), Italian Association of Hospital Gastroenterology and Digestive Endoscopy (AIGO), Italian Association of Gastroenterology and Digestive Endoscopy (SIGE), Italian Society of Maxillofacial Surgery (SICMF), Italian Society of Reconstructive Plastic Surgery and Aesthetics (SICPRE), Italian Society of Gynecology and Obstetrics (SIGO), Italian Society of Neurosurgery (SINch), Italian Association of Hospital Pulmonologist (AIPO), Italian Society of Periodontology (SIdP), Italian Society of Ophthalmology (SOI), Italian Association of Hospital Otorhinolaryngologist (AOOI), Italian Association of Hospital Surgeons (ACOI), Association of Obstetricians Gynecologists Italian Hospital (AOGOI)

\section{ABSTRACT}

Perioperative management of antithrombotic therapy in patients treated with coronary stents undergoing surgery remains poorly defined. Importantly, surgery represents a common reason for premature treatment discontinuation, which is associated with an increased risk in mortality and major adverse cardiac events. However, maintaining antithrombotic therapy to minimize the incidence of perioperative ischemic complications may increase the risk of bleeding complications. Although guidelines provide some recommendations with respect to the perioperative management of antithrombotic therapy, these have been largely developed according to the thrombotic risk of the patient and a definition of the hemorrhagic risk specific to each surgical procedure, key to defining the trade-off between ischemia and bleeding, is not provided. These observations underscore the need for a multidisciplinary collaboration among cardiologists, anesthesiologists, hematologists and surgeons to reach this goal. The present document is an update on practical recommendations for standardizing management of antithrombotic therapy management in patients treated with coronary stents (Surgery After Stenting 2) in various types of surgery according to the predicted individual risk of thrombotic complications against the anticipated risk of surgical bleeding complications. Cardiologists defined the thrombotic risk using a "combined ischemic risk" approach, while surgeons classified surgeries according to their inherent hemorrhagic risk. Finally, a multidisciplinary agreement on the most appropriate antithrombotic treatment regimen in the perioperative phase was reached for each surgical procedure. (J Am Coll Cardiol Intv 2018;11:417-34) @ 2018 by the American College of Cardiology Foundation.

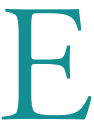
very year, approximately 1 million patients undergo coronary stent implantation in both the United States and Europe $(1,2)$. Up to $15 \%$ and $25 \%$ of these patients undergo some type of invasive diagnostic or surgical procedure within 1 and 5 years after stenting, respectively $(3,4)$. Moreover, it has been estimated that $\sim 10 \%$ of patients on oral anticoagulant (OAC) therapy, some who may have also been treated with coronary stents, undergo surgical interventions every year (5). Perioperative management of antiplatelet and anticoagulant therapies raises important challenges and safety concerns. On 


A B B R E V I A T I O N S
A N D A C R O N Y M S
ACS = acute coronary
syndrome(s)
AF = atrial fibrillation
BMS = bare-metal stent(s)
BVS = bioresorbable vascular
Scaffold
CAD = coronary artery disease
CrCI = creatinine clearance
DAPT = dual antiplatelet
therapy
DES = drug-eluting stent(s)
GPI = glycoprotein llb or IIla
inhibitor
MACE = major adverse cardiac
event(s)
MI = myocardial infarction
NOAC = non-vitamin K oral
anticoagulant
NCS = noncardiac surgery
OAC = oral anticoagulant
PCI = percutaneous coronary
intervention
ST = stent thrombosis
VKA = vitamin K antagonist

the one hand, withholding therapy to reduce the risk of bleeding complications is associated with a heightened risk of ischemic events, including life-threatening stent thrombosis (ST), myocardial infarction (MI), and stroke (6-9). On the other hand, maintaining antithrombotic therapy may increase the risk of bleeding and need for transfusions, which are both known determinants of poor prognosis (3-9).

Defining the trade-off between ischemia and bleeding requires not only an understanding of the thrombotic risk of the individual patient, typically defined by the cardiologist, but also a clear understanding of the hemorrhagic risk specific to each surgical procedure, which requires the expertise of the surgeon. According to guidelines, perioperative management of antithrombotic therapy should be discussed between the surgeon and the cardiologist (10-12). However, guidelines have been developed primarily by cardiologists who may be less informed of the inherent bleeding risk of specific surgical procedures and, subsequently, characterization of the perioperative bleeding risk of each surgical procedure is slightly addressed (10-12).

On this background, the Italian Society of Interventional Cardiology has previously promoted the creation of a task force integrating the expert opinion from a multidisciplinary collaboration among cardiologists, anesthesiologists, hematologists, and surgeons, providing recommendations on the antithrombotic treatment regimen to be used in patients treated with coronary stents undergoing surgical and endoscopic procedures (13). In particular, this led to the creation of a consensus document, called Surgery After Stenting (SAS), providing practical recommendations for standardizing antithrombotic treatment management in various types of surgery based on the predicted individual risk of thrombotic complications against the anticipated risk of surgical bleeding complications. A national registry surveyed the applicability of the recommendations in real-world clinical practice and supported the relative merit of a risk stratification approach for both ischemia and bleeding in patients with coronary stents undergoing cardiac and noncardiac surgery (NCS) (14).

Given the recent advancements in the field of devices, antithrombotic therapy, and surgical techniques, we expand on our previously reported

\section{Withdrawal of} protection

- Increased inflammatory and prothrombotic state

- Increased platelet

activations and aggregation

- Increased coagulant activity
Surgical intervention with increased prothrombotic and inflammatory state -increased cytokines, neuroendocrine inflammatory mediator release -increased platelet adhesiveness and persistently high platelet counts

-increased release of procoagulant factors - Decreased or impaired fibrinolysis

Multiple mechanisms contribute the pathogenesis of stent thrombosis, myocardial infarction, and death in stented patients undergoing surgery including the withdrawal of ischemic protection deriving from discontinuation of antiplatelet therapy, the enhanced prothrombotic and proinflammatory status associated with certain surgeries and the incomplete degree of stent strut coverage which may vary according to stent type. 


\section{CENTRAL ILLUSTRATION Determinants of the "Combined Ischemic Risk"}

\section{Combined Ischemic Risk}

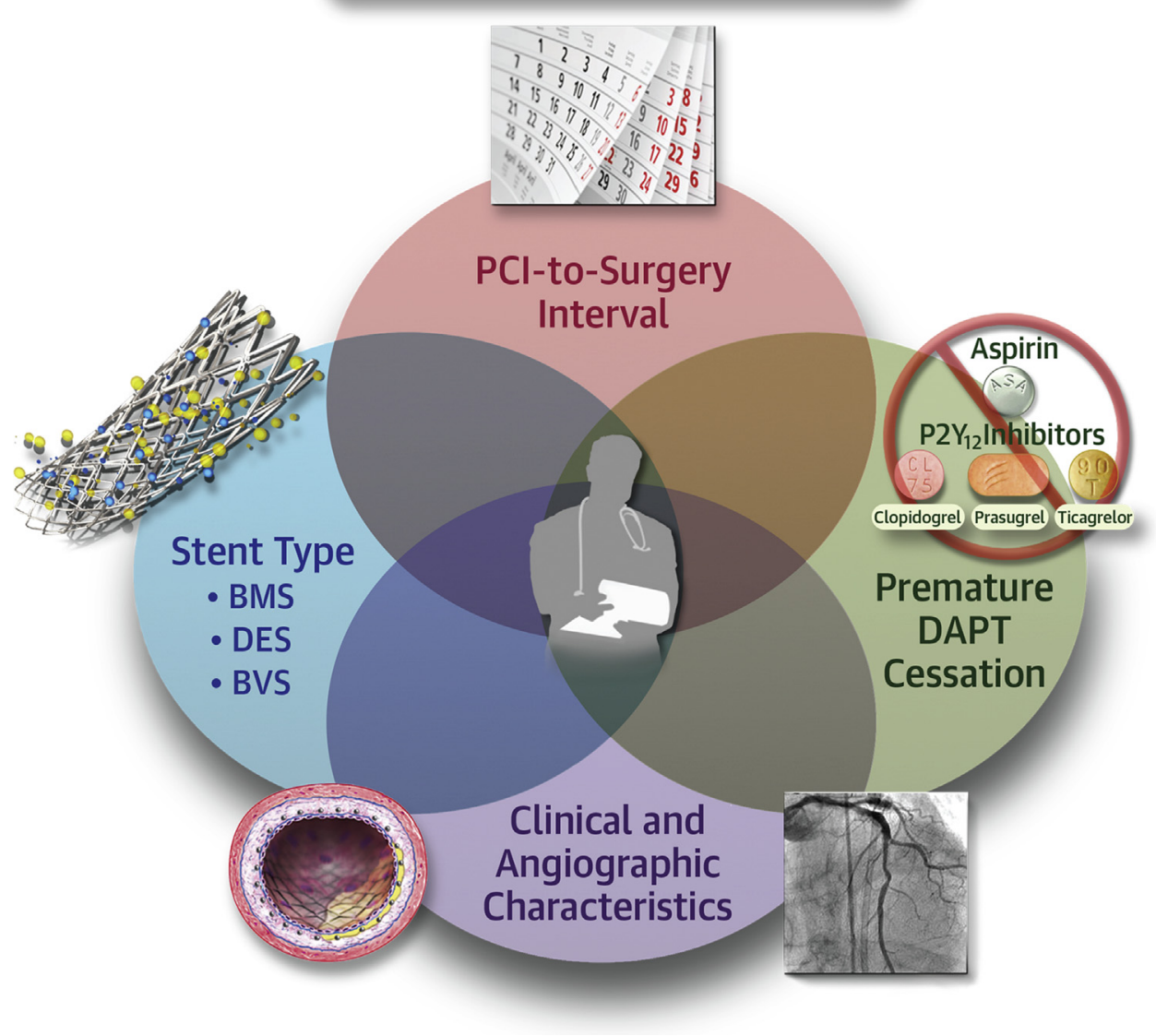

Rossini, R. et al. J Am Coll Cardiol Intv. 2018;11(5):417-34.

The "combined ischemic risk" helps define the thrombotic risk of an individual patient is defined based on multiple determinants, including time from percutaneous coronary intervention $(\mathrm{PCl})$ to surgery, premature cessation of dual antiplatelet therapy (DAPT), clinical (acute coronary syndrome at time of index $\mathrm{PCl}$ procedure, multiple previous myocardial infarction, previous stent thrombosis, left ventricular ejection fraction $<35 \%$, chronic kidney disease, and diabetes mellitus) and angiographic characteristics (angiographic risk features: long or multiple stents, overlapping stents, small stent diameter $[<2.5 \mathrm{~mm}]$, bifurcation lesions, extensive coronary artery disease, incomplete revascularization of the patient), and stent type. According to available data, thrombotic risk and DAPT length in bioresorbable polymer stents are similar for second-generation drug-eluting stents (DES) with durable polymers. Therefore, in the present document the recommendations for bioresorbable polymer stents are the same as for second-generation DES. BMS = bare-metal stent(s); BVS = bioresorbable vascular scaffold.

document, and hereby provide an updated consensus report called SAS 2 .

\section{SAS 2: A MULTIDISCIPLINARY APPROACH ON PERIOPERATIVE ANTITHROMBOTIC MANAGEMENT}

SAS 2 derives from a multidisciplinary collaboration and provides practical recommendations on the perioperative management of antithrombotic therapy in patients treated with coronary stents undergoing cardiac and NCS. These recommendations are summarized in the present document and can be accessed through a workable web application, which can be downloaded at (Stent and Surgery app; https://itunes. apple.com/us/app/stent-surgery/id551350096?mt=8). Italian Society of Interventional Cardiology was responsible for organizing the SAS 2 task force and 
designating a Writing Committee, which was composed of cardiologists, surgeons, anesthesiologists, and hematologists (see the Online Appendix for further details on the organizational structure of SAS 2).

Cardiologists defined the thrombotic risk based on a series of clinical features and procedural characteristics. In particular, the definition of thrombotic risk (low, intermediate, or high) was derived considering angiographic and clinical features leading to the formulation of recommendations for each surgical specialty. Surgeons classified all interventions according to the inherent hemorrhagic risk (low, intermediate, or high) of each specific surgery. In particular, bleeding risk was not solely based on the amount of blood loss, but mostly according to the anticipated difficulty in achieving adequate local hemostasis. In SAS 2 the bleeding risk was defined for $\sim 250$ surgical procedures. Notably, the present recommendations focus mostly on the perioperative bleeding risk related to the surgical procedure rather than to the patient's hemorrhagic risk profile. Finally, a consensus agreement was reached that involved not only cardiologists and surgeons, but also anesthesiologists and hematologists, defining the most appropriate antithrombotic treatment regimen in the perioperative phase for each procedure taking into consideration both the thrombotic and bleeding risk profiles. Importantly, the recommended antithrombotic treatment regimen was not standard to a given thrombotic or bleeding risk profile, but was specific to each individual surgery. In addition, SAS 2 also provides insights on the perioperative management of stented patients concomitantly treated with OAC, in particular those with atrial fibrillation (AF) on therapy with non-vitamin $\mathrm{K}$ oral anticoagulants (NOACs).

\section{EVOLUTION IN STENT TECHNOLOGY AND IMPACT ON PERIOPERATIVE \\ ANTITHROMBOTIC MANAGEMENT}

The use of drug-eluting stents (DES) represents the standard of care for percutaneous coronary intervention (PCI) of coronary artery disease (CAD) $(12,15,16)$. After DES implantation, dual antiplatelet therapy (DAPT) is required to prevent ST while vascular healing and strut endothelialization are ongoing. Surgery represents a very common reason for early discontinuation or interruption of DAPT and is associated with a proinflammatory and prothrombotic milieu that may amplify the risk of ST $(17,18)$ (Figure 1).

The minimally required DAPT duration after DES implantation is therefore a fundamental issue that needs to be considered in patients with coronary stents undergoing surgery. Newer-generation DES have been designed to overcome most of the limitations of first-generation DES and have shown to be associated with a lower risk of ST (see the Online Appendix for details) $(12,15,16)$.

In a large multicenter PCI registry, the interplay between stent type and time from PCI to surgery was independently associated with perioperative cardiac death or MI (19). In this study, new-generation DES showed similar safety to bare-metal stents (BMS) at any time interval between PCI and surgery, and there was a trend toward better safety when surgery occurred between 0 and 6 months after stenting. A further analysis demonstrated that the potential advantage of newer-generation DES was gained between 2 and 6 months after stenting, being the first month after stenting at extremely high risk for all stents (19). Because the thrombotic risk and DAPT length in bioresorbable polymer stents are similar for second-generation DES with durable polymers (10), in the present document the recommendations for bioresorbable polymer stents are the same as for secondgeneration DES.

Bioresorbable vascular scaffolds (BVS) hold the promise of vascular restoration therapy. The large majority of the available clinical data belongs to the Absorb everolimus-eluting bioresorbable vascular scaffold (Abbott Vascular, Santa Clara, California). The latest data suggest an increased risk of ST of any type when compared with new-generation DES, without any clinical advantage up to 3 years (20). As a consequence, in patients treated with BVS, DAPT duration of at least 12 months or even longer have been recommended $(10,21)$. Therefore, patients with current generation BVS should be all considered at high thrombotic risk, if DAPT discontinuation is performed before 12 months. However, this time window should probably be extended, especially after treatment of complex lesions $(10,21)$.

\section{COMBINED ISCHEMIC RISK}

In patients with coronary stents undergoing NCS, the rate of major adverse cardiac events (MACE) ranges from $3 \%$ to $11 \%$ depending on the definition of MACE, the different types of surgeries, and the time from stent implantation (22). Several independent factors may contribute to the increased risk of MACE. In particular, perioperative outcomes after NCS represents a highly complex interplay between time, patient's surgical and cardiac risk, and the need for DAPT. Notably, the 2 main modifiable determinants of ischemic risk are represented by timing from PCI to surgery and premature cessation of DAPT, the latter 
FIGURE 2 Bridging Protocol Using Cangrelor for Patients on Dual Antiplatelet Therapy With Aspirin Plus a P2Y 12 Receptor Inhibitor Referred to Cardiac or Noncardiac Surgery

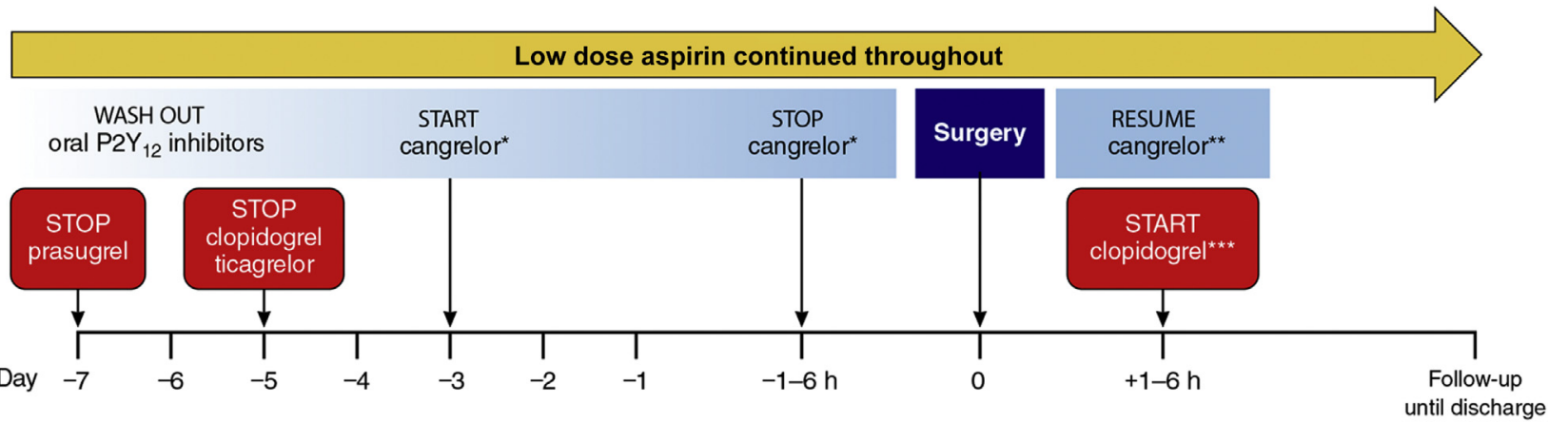

* Initiate within 72 hours from $\mathrm{P}_{2} \mathrm{Y}_{12}$ inhibitor discontinuation at a dose of $0.75 \mu \mathrm{g} / \mathrm{kg} / \mathrm{min}$ (no bolus) for a minimum of 48 hours and a maximum of 7 days. ${ }^{* *}$ If oral administration
not possible
***With 300-600 mg loading dose, as soon as oral administration possible. Prasugrel or ticagrelor discouraged

Clopidogrel and ticagrelor should be discontinued for 5 days and prasugrel for 7 days. Start cangrelor at bridging dose regimen 3 to 4 days after prasugrel discontinuation and 2 to 3 days of clopidogrel and ticagrelor discontinuation and discontinue 1 to 6 h before surgery. Platelet function testing may be considered to help guide timing of starting cangrelor infusion. After surgery, prasugrel and ticagrelor administration should be discouraged and clopidogrel should be resumed with a loading dose as soon as oral administration is possible and the risk of severe bleeding is acceptable. If the use of oral P2 $\mathrm{Y}_{12}$ inhibiting therapy is not possible, post-surgery bridging might be considered. Adapted with permission from Angiolillo et al. (47).

being related to the stent type as well as clinical and angiographic characteristics. On this background, the present document introduces the concept of "combined ischemic risk" (Central Illustration), which is defined according to the following determinants:
TIME FROM PCI TO SURGERY. Patients requiring surgery after PCI are at increased risk of MI and cardiac death compared with patients without CAD (23). The risk of MACE is dependent on the time from stenting to NCS with substantially elevated risk in the

FIGURE 3 Bridging Protocol Using Small-Molecule GPIs for Patients on Dual Antiplatelet Therapy With Aspirin Plus a P2Y 12 Receptor Inhibitor Referred to Cardiac or Noncardiac Surgery

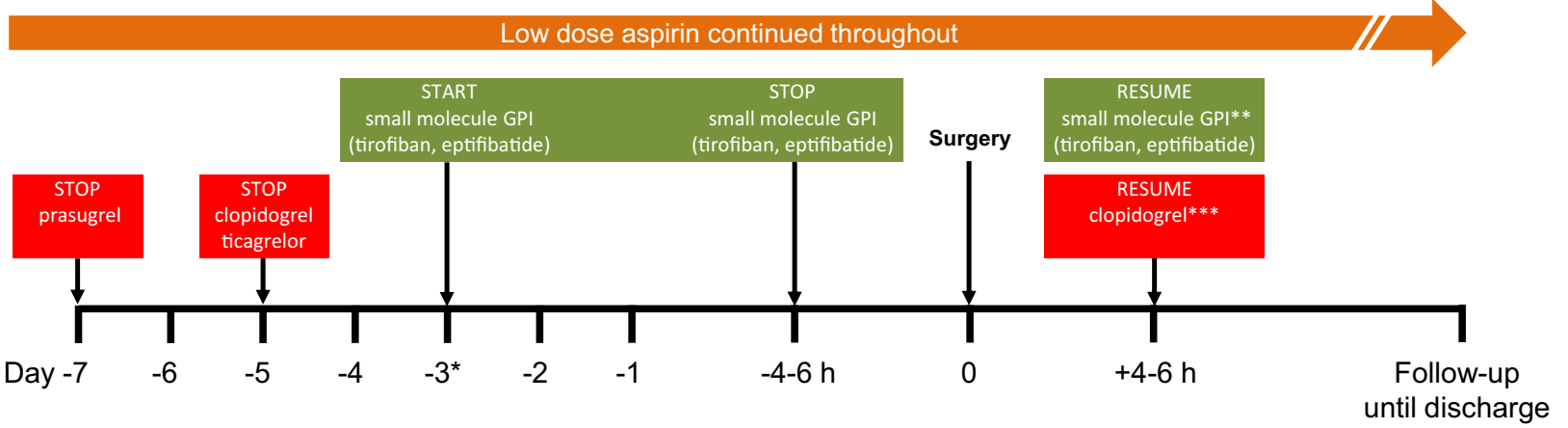

*Tirofiban: $0.1 \mu \mathrm{g} / \mathrm{Kg} / \mathrm{min}$; If creatinine clearance $<50 \mathrm{~mL} / \mathrm{min}$ adjust to $0.05 \mu \mathrm{g} / \mathrm{Kg} / \mathrm{min}$.Eptifibatide: $2.0 \mu \mathrm{g} / \mathrm{Kg} / \mathrm{min}$; If creatinine clearance is $<50 \mathrm{~mL} / \mathrm{min}$, adjust to $1.0 \mu \mathrm{g} / \mathrm{Kg} / \mathrm{min}$.
**If oral administration not possible
***With 300-600 mg loading dose, as soon as oral administration possible. Prasugrel or ticagrelor discouraged

Clopidogrel and ticagrelor should be discontinued for 5 days and prasugrel for 7 days. Bridging with tirofiban or eptifibatide at a maintenance-dosing regimen (no bolus) should be initiated $\sim 72 \mathrm{~h}$ before surgery and continued up to 4 to $6 \mathrm{~h}$ from surgery. In patients with renal impairment, a dose reduction is warranted and earlier suspension ( 8 to $12 \mathrm{~h}$ ) should be considered. After surgery, prasugrel and ticagrelor administration should be discouraged and clopidogrel should be resumed with a loading dose as soon as oral administration is possible and the risk of severe bleeding is acceptable. If the use of oral P2 $\mathrm{Y}_{12}$ inhibiting therapy is not possible, post-surgery bridging might be considered. Adapted with permission from Capodanno et al. (4). GPI = glycoprotein IIb or IIla inhibitor. 
first year after stenting, but not thereafter compared with nonstented patients (24). Although time to surgery and premature cessation of DAPT often coincide, sometimes they are not equivalent, as it is not uncommon that surgery can be performed while on DAPT. Moreover, several studies have shown that the risk of perioperative MACE was dependent on the time from PCI to NCS. Notably, in some of these studies the effect of perioperative maintenance of antiplatelet therapy was either not demonstrated (22,25-27), too short to justify MACE (28), or not addressed $(23,29)$. In addition to the risk of ST, particularly if DAPT is interrupted, surgery is associated with pro-inflammatory and prothrombotic effects that may increase the rate of ischemic complications at the level of the stented vascular segment as well as in the rest of the coronary vasculature (17). However, the optimal timing for NCS after DES-PCI still remains a matter of debate. There are no randomized data to guide the clinician but only evidence from registries. Similar to other studies $(29,30)$, a Danish registry found that beyond the first month after stent implantation, DES-treated patients have the same perioperative risk of MI and cardiac death as surgery in patients without CAD (23). The authors conclude that if surgery cannot be delayed, it might be performed safely between 1 to 3 months after DESPCI in selected patients without high-risk clinical or lesion characteristics (23).

Current guidelines from the European Society of Cardiology recommended that elective surgery requiring discontinuation of the $\mathrm{P}_{2} \mathrm{Y}_{12}$ inhibitor be considered after 1 month, irrespective of the stent type, if aspirin can be maintained throughout the perioperative period (10). In patients with recent MI or other high ischemic risk features requiring DAPT, elective surgery may be postponed for up to 6 months (10). The 2016 American College of Cardiology/ American Heart Association guideline-focused update on duration of DAPT strongly advised against elective NCS within 3 months after DES implantation. Surgery may be considered 3 to 6 months after DESPCI, with discontinuation of DAPT if the delayed surgical risk is greater than the risk of ST, but optimally should be performed after 6 months (12). They also recommend delaying nonurgent NCS for at least 1 month after BMS implantation (12).

PREMATURE CESSATION OF DAPT. A period of DAPT after PCI is required to prevent stent-related thrombotic complications while vascular healing and platform endothelialization are ongoing, a process that lasts several months (31). Premature cessation of DAPT during this period is associated with a high risk for ischemic events $(25,32,33)$. Based on the results of several studies, the European Society of Cardiology and American College of Cardiology/American Heart Association guidelines have shortened the period of mandatory DAPT duration after second generation DES to 6 months for patients with stable CAD $(10,12,16)$. However, according to the type of stent used or the procedural complexity (e.g., number of lesion or vessels treated, stent number and total length, type of lesion), and always after a careful balance of ischemic and bleeding risk, a premature cessation of DAPT can be considered $(10,12,34)$.

\section{CLINICAL AND ANGIOGRAPHIC CHARACTERISTICS.} One of the most powerful predictors of a future cardiac adverse event is the history of a prior ischemic event within the past year (35). In a large cohort of patients from the Veterans Affairs Health Administration hospitals, the ischemic perioperative risk was significantly higher in ACS patients (36). Other predictors of MACE include age, presence of certain clinical risk factors (e.g., diabetes mellitus and renal failure), congestive heart failure, or low ejection fraction (37).

Although the risk of an ischemic event declines after 6 months from PCI $(23,36)$, angiographic characteristics may have an impact on long-term clinical outcomes and differentiate patients who may benefit from prolonged ( $>6$ to 12 months) DAPT. In the 5-year follow-up of the SYNTAX (Synergy between PCI with Taxus and cardiac surgery) trial, the number of overlapping stents was strongly related to MACE (38). These findings might be reasonably explained by the extent of atherosclerosis and the need for complex revascularization that exposed the patient to an increased risk of both early and late ischemic events (39). This may explain observations from a recent study of patients treated with new-generation DES showing an incremental benefit of prolonging DAPT duration as function of the complexity of angiographic and procedural characteristics (34).

STENT TYPE. The pathophysiology of ST is multifactorial, and the type of stent plays a contributing role (31). Historical studies showed that NCS performed early after balloon angioplasty is not associated with an increased risk of cardiac events (40). There is conflicting evidence on the impact of timing of NCS by stent type on MACE. A study of the Ontario stent registry cohort reported the optimal time of surgery to be 46 to 180 days for BMS and $>180$ days for DES (41). Conversely, in the retrospective Veterans Affairs cohort study, the increased rate of MACE was related to nonelective surgical admission, recent $\mathrm{MI}(<6$ months) and to a Revised Cardiac Risk Index $>2$, but 


\begin{tabular}{|c|c|c|c|c|c|c|c|c|c|c|}
\hline \multirow[b]{2}{*}{$\begin{array}{l}\text { Surgery to } \\
\text { PCI Time }\end{array}$} & \multicolumn{5}{|c|}{$\begin{array}{l}\text { PCI Patients With Clinical* or Angiographic* } \\
\text { Increased Ischemic Risk Characteristics }\end{array}$} & \multicolumn{5}{|c|}{$\begin{array}{l}\text { PCI Patients Without Clinical* or Angiographic* } \\
\text { Increased Ischemic Risk Characteristics }\end{array}$} \\
\hline & РОВA & BMS & $\begin{array}{l}\text { First- } \\
\text { Generation } \\
\text { DES }\end{array}$ & $\begin{array}{c}\text { Second- } \\
\text { Generation } \\
\text { DES }+\end{array}$ & BVS & РОВA & BMS & $\begin{array}{c}\text { First- } \\
\text { Generation } \\
\text { DES }\end{array}$ & $\begin{array}{c}\text { Second- } \\
\text { Generation } \\
\text { DES }+\end{array}$ & BVS \\
\hline$<1$ months & High & High & High & High & High & $\begin{array}{l}\text { High ( }<2 \text { weeks) } \\
\text { intermediate }\end{array}$ & High & High & High & High \\
\hline $1-3$ months & Intermediate & High & High & High & High & Low & Intermediate & High & Intermediate & High \\
\hline 4-6 months & Intermediate & High & High & Intermediate/high & High & Low & Low/intermediate & Intermediate & Low/intermediate & High \\
\hline 6-12 months & Intermediate & Intermediate & Intermediate & Intermediate & High & Low & Low & Intermediate & Low & High \\
\hline$>12$ months & Low & Low & Low & Low & Undetermined & Low & Low & Low & Low & Undetermined \\
\hline
\end{tabular}

not to the stent type when the timing of surgery was beyond 6 months after PCI (42). Of note, the risk of adverse events was higher within the first 3 months of PCI and it was worse with BMS compared with DES. Other studies, confirmed a benefit of DES over BMS also after 6 months $(24,36)$. Although a selection bias cannot be excluded, these studies showed that the use of BMS are not safer than the newer-generation DES. Moreover, ST was very rare and most of the observed perioperative MIs were due to lesion progression or lesions not revascularized during the index PCI (24).

\section{BRIDGING ANTIPLATELET THERAPY}

Bridging of antiplatelet therapy indicates a strategy of temporary transition with an intravenous antiplatelet agent in patients requiring DAPT. This strategy is usually reserved for patients deemed at high thrombotic risk (who thus cannot safely interrupt oral antiplatelet therapy) undergoing nondeferrable surgery

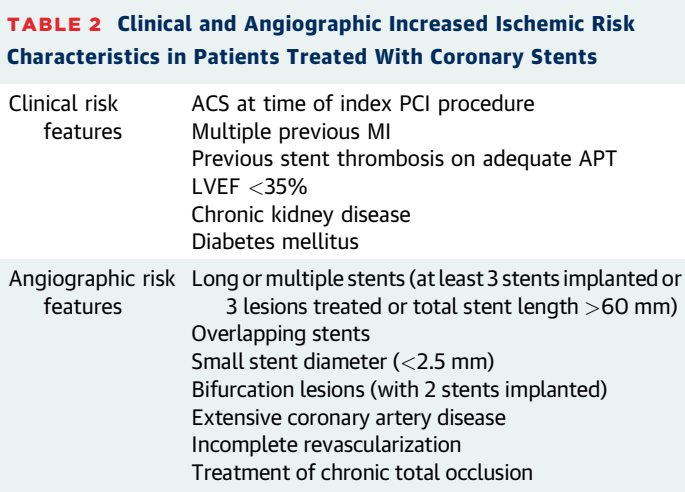

ACS = acute coronary syndrome(s); APT = antiplatelet therapy; LVEF = left ventricular ejection fraction; $\mathrm{MI}=$ myocardial infarction; $\mathrm{PCl}=$ percutaneous coronary intervention. at high risk of bleeding, which requires a predictable interruption of platelet inhibition at the time of surgery $(4,5,10,14)$. Data to inform on bridging of antiplatelet therapy are limited and there are currently no antiplatelet agents approved by drug regulating agencies for this indication. In the current European Society of Cardiology guidelines, a bridging strategy with intravenous antiplatelet agents may be considered if both oral antiplatelet agents have to be discontinued perioperatively, especially within 1 month after PCI (10).

The only intravenous antiplatelet agents available for clinical use, and thus of potential utility for bridging, include cangrelor (Figure 2) and glycoprotein IIb or IIIa inhibitors (GPIs) (Figure 3). Cangrelor is an intravenous $\mathrm{P}_{2} \mathrm{Y}_{12}$ inhibitor (43). Given that cangrelor is not renally cleared, there is no need for dose adjustment in patients with impaired renal function. Reversible binding to $\mathrm{P}_{2} \mathrm{Y}_{12}$ receptors of this agent along with its very short half-life (3 to $6 \mathrm{~min}$ ) allows for resumption of platelet function within $60 \mathrm{~min}$ of infusion cessation (44). Cangrelor was recently approved for the reduction of thrombotic cardiovascular events in patients with CAD undergoing PCI who have not received an oral $\mathrm{P}_{2} \mathrm{Y}_{12}$ inhibitor before $\mathrm{PCI}$ (45). Cangrelor has also been specifically tested against placebo as a bridging agent among thienopyridinetreated patients undergoing coronary artery bypass grafting surgery in the BRIDGE (Bridging Antiplatelet Therapy With Cangrelor in Patients Undergoing Cardiac Surgery) trial (46). However, there are no randomized trials of bridging with cangrelor in NCS, with data deriving from anecdotal experience. In line with the BRIDGE trial approach, cangrelor at a bridging dose regimen can be commenced at the time of the next expected dose of the $\mathrm{P}_{2} \mathrm{Y}_{12}$ inhibitor and stopped up to $1 \mathrm{~h}$ before the start of surgery (Figure 2). However, because the oral agents persist with optimal levels of 


\begin{tabular}{|c|c|c|c|c|c|}
\hline \multirow{2}{*}{$\begin{array}{l}\text { Hemorrhagic } \\
\text { Risk }\end{array}$} & \multirow[b]{2}{*}{ Type of Surgery } & \multirow{2}{*}{$\begin{array}{c}\text { Antiplatelet/ } \\
\text { Anticoagulant } \\
\text { Drug }\end{array}$} & \multicolumn{3}{|c|}{ Thrombotic Risk } \\
\hline & & & Low & Intermediate & High \\
\hline \multirow[t]{3}{*}{ Low } & \multirow{3}{*}{$\begin{array}{l}\text { Hernioplasty } \\
\text { Plastic surgery of incisional } \\
\quad \text { hernias Cholecystectomy } \\
\text { Appendectomy } \\
\text { Colectomy } \\
\text { Gastric resection } \\
\text { Intestinal resection } \\
\text { Breast surgery }\end{array}$} & ASA & Continue & $\begin{array}{l}\text { Elective surgery: postpone } \\
\text { Nondeferrable surgery: continue }\end{array}$ & $\begin{array}{l}\text { Elective surgery: postpone } \\
\text { Nondeferrable surgery: continue }\end{array}$ \\
\hline & & $\begin{array}{l}\mathrm{P} \mathrm{Y}_{12} \text { receptor } \\
\text { inhibitors }\end{array}$ & $\begin{array}{l}\text { Discontinue } 5 \text { days before for } \\
\text { clopidogrel/ticagrelor, } \\
7 \text { days before for prasugrel } \\
\text { Resume within } 24-72 \mathrm{~h} \text { (with a } \\
\text { loading dose) }\end{array}$ & $\begin{array}{l}\text { Elective surgery: postpone } \\
\text { Nondeferrable surgery: continue }\end{array}$ & $\begin{array}{l}\text { Elective surgery: postpone } \\
\text { Nondeferrable surgery: continue }\end{array}$ \\
\hline & & NOAC & & \multicolumn{2}{|l|}{$\begin{array}{l}\text { Discontinue at least } 24-96 \mathrm{~h} \text { before } \dagger \\
\text { Resume within } 48-72 \mathrm{~h} \neq\end{array}$} \\
\hline \multirow[t]{3}{*}{ Intermediate } & \multirow{3}{*}{$\begin{array}{l}\text { Hemorrhoidectomy } \\
\text { Splenectomy } \\
\text { Gastrectomy } \\
\text { Obesity surgery } \\
\text { Rectal resection } \\
\text { Thyroidectomy }\end{array}$} & ASA & Continue & $\begin{array}{l}\text { Elective surgery: postpone } \\
\text { Nondeferrable surgery: continue }\end{array}$ & $\begin{array}{l}\text { Elective surgery: postpone } \\
\text { Nondeferrable surgery: continue }\end{array}$ \\
\hline & & $\begin{array}{l}\mathrm{P} 2 \mathrm{Y}_{12} \text { receptor } \\
\text { inhibitors }\end{array}$ & $\begin{array}{l}\text { Discontinue } 5 \text { days before for } \\
\text { clopidogrel/ticagrelor, } \\
7 \text { days before for prasugrel } \\
\text { Resume within } 24-72 \mathrm{~h} \text { (with a } \\
\text { loading dose) }\end{array}$ & $\begin{array}{l}\text { Elective surgery: postpone } \\
\text { Nondeferrable surgery: } \\
\text { - Discontinue } 5 \text { days before for } \\
\text { clopidogrel/ticagrelor, } 7 \text { days } \\
\text { before for prasugrel } \\
\text { - Resume within } 24-72 \mathrm{~h}^{*} \text { (with } \\
\text { a loading dose) }\end{array}$ & $\begin{array}{l}\text { Elective surgery: postpone } \\
\text { Nondeferrable surgery: } \\
\text { - Discontinue } 5 \text { days before } \\
\text { for clopidogrel/ticagrelor, } \\
7 \text { days before for prasugrel } \\
\text { - Resume within 24-72 h* } \\
\text { (with a loading dose) } \\
\text { Consider. bridge therapy* }\end{array}$ \\
\hline & & NOAC & & $\begin{array}{c}\text { Discontinue at least } 24-96 \mathrm{~h} \text { before } \\
\text { Resume within } 48-72 \mathrm{~h} \neq\end{array}$ & \\
\hline \multirow[t]{3}{*}{ High } & \multirow[t]{3}{*}{$\begin{array}{l}\text { Hepatic resection } \\
\text { Duodenocefalopancreasectomy }\end{array}$} & ASA & Discontinue & $\begin{array}{l}\text { Elective surgery: postpone } \\
\text { Nondeferrable surgery: continue }\end{array}$ & $\begin{array}{l}\text { Elective surgery: postpone } \\
\text { Nondeferrable surgery: continue }\end{array}$ \\
\hline & & $\begin{array}{l}\mathrm{P} 2 \mathrm{Y}_{12} \text { receptor } \\
\text { inhibitors }\end{array}$ & $\begin{array}{l}\text { Discontinue } 5 \text { days before for } \\
\text { clopidogrel/ticagrelor, } \\
7 \text { days before for prasugrel } \\
\text { Resume within } 24-72 \mathrm{~h} \text { (with a } \\
\text { loading dose) }\end{array}$ & $\begin{array}{l}\text { Elective surgery: postpone } \\
\text { Nondeferrable surgery: } \\
\text { - Discontinue } 5 \text { days before for } \\
\text { clopidogrel/ticagrelor, } 7 \text { days } \\
\text { before for prasugrel } \\
\text { - Resume within } 24-72 \mathrm{~h}^{*} \text { (with } \\
\text { a loading dose) }\end{array}$ & $\begin{array}{l}\text { Elective surgery: postpone } \\
\text { Nondeferrable surgery: } \\
\text { - Discontinue } 5 \text { days before } \\
\text { for clopidogrel/ticagrelor, } \\
7 \text { days before for prasugrel } \\
\text { - Resume within 24-72 h* } \\
\text { (with a loading dose) } \\
\text { Consider bridge therapy* }\end{array}$ \\
\hline & & NOAC & & \multicolumn{2}{|l|}{$\begin{array}{l}\text { Discontinue at least } 48-96 \mathrm{~h} \text { before } \dagger \\
\text { Resume within } 48-72 \mathrm{~h} \neq\end{array}$} \\
\hline
\end{tabular}

$\mathrm{P}_{2} \mathrm{Y}_{12}$ inhibition after drug discontinuation (clopidogrel and ticagrelor should be discontinued for 5 days before surgery and for 7 days with prasugrel), it is reasonable to wait to start cangrelor bridging up to 3 to 4 days after prasugrel discontinuation and 2 to 3 days of clopidogrel and ticagrelor discontinuation to minimize the duration of infusion (47). This also has implications on costs due to the fact that patients need to be hospitalized to receive drug infusion (thus reducing the time of hospitalization) as well as that it would reduce the costs of the drug itself.

Alternatively, small-molecule GPIs (eptifibatide or tirofiban) may be considered for bridging therapy $(10,12)$. Compared with cangrelor however, these agents have a slower offset of action and they do not target the $\mathrm{P}_{2} \mathrm{Y}_{12}$ receptor. In addition, as they are renally cleared, dose adjustments are required among patients with impaired renal function. Also on the contrary to cangrelor, there are no studies that have evaluated a bridging dosing regimen with GPIs, which is thus used at the ACS or PCI dosing regimen.
Therefore, the potential for bleeding complications is indeed higher given the prolonged (i.e., days) infusion of this dosing regimen that leads to near complete suppression of platelet function. There are no randomized trials on bridging with small molecule GPIs and data derive from observational studies $(48,49)$. After previously mentioned recommended discontinuation timeframes of oral $\mathrm{P}_{2} \mathrm{Y}_{12}$ inhibitors, infusion should be commenced 3 days before surgical intervention. GPI infusion should be interrupted at least $4 \mathrm{~h}$ before surgery ( $8 \mathrm{~h}$ in patients with creatinine clearance $<50 \mathrm{ml} / \mathrm{min}$ ) (Figure 3 ).

Once successful hemostasis has been achieved, oral $\mathrm{P}_{12} \mathrm{Y}_{12}$ inhibiting therapy should be resumed within 24 to $48 \mathrm{~h}$ with the use of a loading dose. In patients with increased bleeding risk, clopidogrel should be preferred over prasugrel or ticagrelor. If the use of oral $\mathrm{P}_{2} \mathrm{Y}_{12}$ inhibiting therapy is not possible, for example, if gastrointestinal function has not yet recovered (e.g., abdominal surgery), intravenous infusion of antiplatelet agents (cangrelor or GPI) should be restarted 


\begin{tabular}{|c|c|c|c|c|c|}
\hline \multirow{2}{*}{$\begin{array}{l}\text { Hemorrhagic } \\
\text { Risk }\end{array}$} & \multirow[b]{2}{*}{ Type of Surgery } & \multirow{2}{*}{$\begin{array}{c}\text { Antiplatelet/ } \\
\text { Anticoagulant Drug }\end{array}$} & \multicolumn{3}{|c|}{ Thrombotic Risk } \\
\hline & & & Low & Intermediate & High \\
\hline \multirow[t]{3}{*}{ Low } & - & ASA & - & - & - \\
\hline & & $\begin{array}{l}\mathrm{P}_{2} \mathrm{Y}_{12} \text { receptor } \\
\text { inhibitors }\end{array}$ & - & - & - \\
\hline & & NOAC & - & - & - \\
\hline \multirow[t]{3}{*}{ Intermediate } & $\begin{array}{l}\text { Valve repair } \\
\text { Valve replacement OPCAB }\end{array}$ & ASA & Continue & $\begin{array}{l}\text { Elective surgery: postpone } \\
\text { Nondeferrable surgery: continue }\end{array}$ & $\begin{array}{l}\text { Elective surgery: postpone } \\
\text { Nondeferrable surgery: continue }\end{array}$ \\
\hline & $\begin{array}{l}\text { CABG } \\
\text { Minithoracotomy } \\
\text { TA-TAVI } \\
\text { TAo-TAVI }\end{array}$ & $\begin{array}{l}\mathrm{P}_{2} \mathrm{Y}_{12} \text { receptor } \\
\text { inhibitors }\end{array}$ & $\begin{array}{l}\text { Discontinue } 5 \text { days before for } \\
\text { clopidogrel/ticagrelor, } 7 \text { days } \\
\text { before for prasugrel } \\
\text { Resume within } 24-72 \text { h (with a } \\
\text { loading dose) }\end{array}$ & $\begin{array}{l}\text { Elective surgery: postpone } \\
\text { Nondeferrable surgery: } \\
\text { - Discontinue } 5 \text { days before for } \\
\text { clopidogrel/ticagrelor, } 7 \text { days } \\
\text { before for prasugrel } \\
\text { - Resume within } 24-72 \text { h* (with } \\
\text { a loading dose) }\end{array}$ & $\begin{array}{l}\text { Elective surgery: postpone } \\
\text { Nondeferrable surgery: } \\
\text { - Discontinue } 5 \text { days before } \\
\text { for clopidogrel/ticagrelor, } \\
7 \text { days before for prasugrel } \\
\text { - Resume within 24-72 h* } \\
\text { (with a loading dose) } \\
\text { Consider bridge therapy } \dagger\end{array}$ \\
\hline & & NOAC & & $\begin{array}{l}\text { Discontinue at least } 24-96 \mathrm{~h} \text { before } \neq \\
\text { Resume within } 48-72 \mathrm{~h} \S\end{array}$ & \\
\hline \multirow[t]{3}{*}{ High risk } & $\begin{array}{l}\text { Reintervention } \\
\text { Endocarditis }\end{array}$ & ASA & Continue & $\begin{array}{l}\text { Elective surgery: postpone } \\
\text { Nondeferrable surgery: continue }\end{array}$ & $\begin{array}{l}\text { Elective surgery: postpone } \\
\text { Nondeferrable surgery: continue }\end{array}$ \\
\hline & $\begin{array}{l}\text { CABG in PCI failure } \\
\text { Aortic dissection } \\
\text { Aortic surgery } \\
\text { Surgery with expected CEC } \\
\quad \text { time }>120 \text { min }\end{array}$ & $\begin{array}{c}\mathrm{P}_{2} \mathrm{Y}_{12} \text { receptor } \\
\text { inhibitors }\end{array}$ & $\begin{array}{l}\text { Discontinue } 5 \text { days before for } \\
\text { clopidogrel/ticagrelor, } 7 \text { days } \\
\text { before for prasugrel } \\
\text { Resume within } 24-72 \text { h (with a } \\
\text { loading dose) }\end{array}$ & $\begin{array}{l}\text { Elective surgery: postpone } \\
\text { Nondeferrable surgery: } \\
\text { - Discontinue } 5 \text { days before for } \\
\text { clopidogrel/ticagrelor, } 7 \text { days } \\
\text { before for prasugrel } \\
\text { - Resume within 24-72 } \mathrm{h}^{*} \text { (with } \\
\text { a loading dose) }\end{array}$ & $\begin{array}{l}\text { Elective surgery: postpone } \\
\text { Nondeferrable surgery: } \\
\text { - Discontinue } 5 \text { days before } \\
\text { for clopidogrel/ticagrelor, } \\
7 \text { days before for prasugrel } \\
\text { - Resume within 24-72 h* } \\
\text { (with a loading dose) } \\
\text { Consider bridge therapy } \dagger\end{array}$ \\
\hline & & NOAC & & $\begin{array}{c}\text { Discontinue at least } 48-96 \mathrm{~h} \text { before } \ddagger \\
\text { Resume within } 48-72 \mathrm{~h} \S\end{array}$ & \\
\hline \multicolumn{6}{|c|}{$\begin{array}{l}\text { Use of } \mathrm{P}_{12} \text { receptor inhibitors is to be considered in association with ASA. *Point-of-care hemostatic testing, if available, may reduce resuming time. }+ \text { Collegial discussion of risk, even with family or patient. } \\
\neq \text { Evaluate creatinine clearance and type of NOAC. §As soon as possible, once adequate hemostasis has been achieved (consider bridge therapy in patients in whom resumption of full-dose anticoagulation } \\
\text { may carry a bleeding risk that could outweigh the risk of cardioembolism). }\end{array}$} \\
\hline \multicolumn{6}{|c|}{$\begin{array}{l}\mathrm{CABG}=\text { coronary artery bypass grafting; } \mathrm{CEC}=\text { extracorporeal circulation; } \mathrm{OPCAB}=\text { off-pump coronary artery bypass; } \mathrm{PCl}=\text { percutaneous coronary intervention or coronary angioplasty; } \mathrm{TA}=\text { transapical; } \\
\mathrm{TAo}=\text { transaortic; TAVR = transcatheter aortic valve replacement; other abbreviations as in Table } 3 .\end{array}$} \\
\hline
\end{tabular}

following surgery, after careful evaluation of the bleeding risk; following recovery of gastrointestinal function, therapy with $\mathrm{P}_{2} \mathrm{Y}_{12}$ inhibitors should be resumed with a loading dose, after which the infusion of intravenous antiplatelet agents can be stopped. Because thrombotic complications occur most frequently soon after surgery, close post-operative clinical and electrocardiographic monitoring is strongly encouraged.

\section{SURGERY AFTER STENTING: PRACTICAL RECOMMENDATIONS FOR PERIOPERATIVE MANAGEMENT OF ANTIPLATELET THERAPY}

Perioperative management of antiplatelet therapy should be judiciously decided for stented patients undergoing surgical or endoscopic procedures. In particular, the individual's thrombotic risk as well as the hemorrhagic risk related to the specific procedure need to be taken into consideration. The thrombotic risk corresponds to the essential need for DAPT and derives from the time from PCI to surgery, clinical and angiographic characteristics, and stent type, and is classified as low, intermediate and high (Tables 1 and 2). In patients undergoing surgery early after PCI (within 1 month and up to 3 months), there is still an increased risk even if DAPT therapy is maintained. It is recommended that high-risk patients be referred to centers where the most minimally invasive therapies such as pure laparoscopic, robotic assisted procedures and new-generation lasers are available.

ELECTIVE SURGery. As shown in Tables 3 to 6 and Online Tables 1 to 11, the vast majority of procedures may be performed while on aspirin, with the possible exception of surgeries at extremely high risk of bleeding (e.g., neurosurgery). The POISE-2 (Perioperative Ischemic Evaluation-2) trial showed that perioperative aspirin use had no significant effect on the combined risk of death or nonfatal MI in patients undergoing NCS (50). Nevertheless, it is important to note in this study only $4 \%$ of patients were treated with stents. Moreover, patients with implantation of DES within 1 year and BMS $<6$ weeks were excluded. Therefore, the primary results of the POISE- 2 trial 


\begin{tabular}{|c|c|c|c|c|c|}
\hline \multirow{2}{*}{$\begin{array}{l}\text { Hemorrhagic } \\
\text { Risk }\end{array}$} & \multirow[b]{2}{*}{ Type of Surgery } & \multirow{2}{*}{$\begin{array}{c}\text { Antiplatelet/ } \\
\text { Anticoagulant Drug }\end{array}$} & \multicolumn{3}{|c|}{ Thrombotic Risk } \\
\hline & & & Low & Intermediate & High \\
\hline \multirow[t]{3}{*}{ Low } & \multirow{3}{*}{$\begin{array}{l}\text { Carotid endarterectomy } \\
\text { Bypass or endarterectomy } \\
\text { of lower extremity } \\
\text { EVAR } \\
\text { TEVAR } \\
\text { Limb amputations }\end{array}$} & ASA & Continue & $\begin{array}{l}\text { Consider PTA or stenting } \\
\text { Elective surgery: not } \\
\text { contraindicated. } \\
\text { Nondeferrable surgery: continue }\end{array}$ & $\begin{array}{l}\text { Consider PTA or stenting } \\
\text { Elective surgery: postpone at } \\
\quad \text { least } 30 \text { days after PCI. } \\
\text { Nondeferrable surgery: continue }\end{array}$ \\
\hline & & $\begin{array}{l}\mathrm{P} \mathrm{Y}_{12} \text { receptor } \\
\text { inhibitors }\end{array}$ & $\begin{array}{l}\text { Discontinue } 5 \text { days before for } \\
\text { clopidogrel/ticagrelor, } 7 \text { days } \\
\text { before for prasugrel } \\
\text { Resume within } 24-72 \mathrm{~h} \text { (with a } \\
\text { loading dose) }\end{array}$ & $\begin{array}{l}\text { Consider PTA or stenting } \\
\text { Elective surgery: not } \\
\text { contraindicated. } \\
\text { Nondeferrable surgery: continue }\end{array}$ & $\begin{array}{l}\text { Consider PTA or stenting } \\
\text { Elective surgery: postpone at } \\
\quad \text { least } 30 \text { days after PCI. } \\
\text { Nondeferrable surgery: continue }\end{array}$ \\
\hline & & NOAC & & $\begin{array}{l}\text { Discontinue at least } 24-48 \mathrm{~h} \text { before* } \\
\text { Resume within } 48-72 \mathrm{~h} \dagger\end{array}$ & \\
\hline \multirow[t]{3}{*}{ Intermediate } & \multirow[t]{3}{*}{$\begin{array}{l}\text { Open abdominal aorta } \\
\text { surgery }\end{array}$} & ASA & Continue & $\begin{array}{l}\text { Elective surgery: postpone or } \\
\text { consider EVAR } \\
\text { Nondeferrable surgery: continue }\end{array}$ & $\begin{array}{l}\text { Elective surgery: postpone or } \\
\text { consider EVAR } \\
\text { Nondeferrable surgery: continue }\end{array}$ \\
\hline & & $\begin{array}{c}\mathrm{P} \mathrm{Y}_{12} \text { receptor } \\
\text { inhibitors }\end{array}$ & $\begin{array}{l}\text { Discontinue } 5 \text { days before for } \\
\text { clopidogrel/ticagrelor, } 7 \text { days } \\
\text { before for prasugrel } \\
\text { Resume within } 24-72 \mathrm{~h} \text { (with a } \\
\text { loading dose) }\end{array}$ & $\begin{array}{l}\text { Elective surgery: postpone or } \\
\text { consider EVAR } \\
\text { Nondeferrable surgery: continue }\end{array}$ & $\begin{array}{l}\text { Elective surgery: postpone or } \\
\text { consider EVAR } \\
\text { Nondeferrable surgery: continue }\end{array}$ \\
\hline & & NOAC & & $\begin{array}{l}\text { Discontinue at least } 24-96 \mathrm{~h} \text { before* } \\
\text { Resume within } 48-72 \mathrm{~h} \dagger\end{array}$ & \\
\hline \multirow[t]{3}{*}{ High } & \multirow[t]{3}{*}{$\begin{array}{l}\text { Open thoracic and } \\
\text { thoracoabdominal } \\
\text { surgery }\end{array}$} & ASA & Discontinue & $\begin{array}{l}\text { Elective surgery: postpone or } \\
\text { consider EVAR } \\
\text { Nondeferrable surgery: continue }\end{array}$ & $\begin{array}{l}\text { Elective surgery: postpone or } \\
\quad \text { consider EVAR } \\
\text { Nondeferrable surgery: continue }\end{array}$ \\
\hline & & $\begin{array}{l}\mathrm{P} 2 \mathrm{Y}_{12} \text { receptor } \\
\text { inhibitors }\end{array}$ & $\begin{array}{l}\text { Discontinue } 5 \text { days before for } \\
\text { clopidogrel/ticagrelor, } 7 \text { days } \\
\text { before for prasugrel } \\
\text { Resume within } 24-72 \mathrm{~h} \text { (with a } \\
\text { loading dose) }\end{array}$ & $\begin{array}{l}\text { Elective surgery: postpone or } \\
\text { consider EVAR } \\
\text { Nondeferrable surgery: continue }\end{array}$ & $\begin{array}{l}\text { Elective surgery: postpone or } \\
\text { consider EVAR } \\
\text { Nondeferrable surgery: continue }\end{array}$ \\
\hline & & NOAC & & $\begin{array}{l}\text { Discontinue at least } 48-96 \mathrm{~h} \text { before* } \\
\text { Resume within } 48-72 \mathrm{~h} \dagger\end{array}$ & \\
\hline
\end{tabular}

Use of $\mathrm{P}_{2} \mathrm{Y}_{12}$ receptor inhibitors is to be considered in association with ASA. In patients receiving therapy with NOACs and candidates for carotid artery stenting or peripheral artery percutaneous transluminal angioplasty (PTA) or stenting dual antiplatelet therapy (and NOAC) should be continued for a variable period (1-3 months) after the procedure. *Evaluate creatinine clearance and type of NOAC. †As soon as possible, once adequate hemostasis has been achieved (consider bridge therapy in patients in whom resumption of full-dose anticoagulation may carry a bleeding risk that could outweigh the risk of cardioembolism).

EVAR = endovascular repair for aortic aneurysm; TEVAR = thoracic endovascular aortic/aneurysm repair; other abbreviations as in Tables 3 and 4.

cannot be applied to stented patients undergoing surgery and accordingly not considered in the SAS 2 . However, a post hoc analysis of patients with a history of PCI $(n=470)$ in the POISE-2 trial was recently reported (51). In particular, compared with placebo, aspirin reduced the risk for the composite of death or myocardial infarction by $50 \%$ (absolute risk difference $5.5 \%$ ) among patients with prior PCI regardless of stent type and time of implantation. This data supports the hypothesized benefit of continuing or resuming low-dose aspirin during the perioperative period among patients with previous PCI having NCS.

When a washout of $\mathrm{P}_{2} \mathrm{Y}_{12}$ inhibiting therapy is required, this should be performed judiciously according to the timing of surgery: 5 days for clopidogrel and ticagrelor and 7 days for prasugrel. Recent data from a large observational study in coronary artery bypass grafting patients demonstrated that discontinuation 3 days before surgery, as opposed to 5 days, did not increase the incidence of major bleeding complications with ticagrelor, but did with clopidogrel
(52). The incidence of coronary artery bypass graftingrelated major bleeding was high when ticagrelor or clopidogrel was discontinued $<24 \mathrm{~h}$ before surgery. These data were confirmed in propensity scorematched analyses among patients with ACS undergoing coronary artery bypass grafting (53). The use of preoperative ticagrelor with or without aspirin compared with aspirin alone was associated with similar degree of bleeding but with an over 2-fold increase in platelet transfusion $(13.5 \%$ vs. $6.0 \%$; $\mathrm{p}=0.009)$. Only in patients receiving ticagrelor 1 day before or up until surgery was there a $>3$-fold increase in severe bleeding (52). On the basis of these findings, in selected cases, surgery might be performed after 3 days of ticagrelor discontinuation, which is also in line with the most recent European Society of Cardiology guideline update on DAPT (10). This option might be considered in patients with recent PCI (up to 1 to 3 months before surgery), in whom bridge therapy may not be feasible. Ultimately, the use of vorapaxar, a platelet protease-activated receptor 1 inhibitor 


\begin{tabular}{|c|c|c|c|c|c|}
\hline \multirow[b]{2}{*}{$\begin{array}{l}\text { Hemorrhagic } \\
\text { Risk }\end{array}$} & \multirow[b]{2}{*}{ Type of Surgery } & \multirow[b]{2}{*}{$\begin{array}{c}\text { Antiplatelet/ } \\
\text { Anticoagulant Drug }\end{array}$} & \multicolumn{3}{|c|}{ Thrombotic Risk } \\
\hline & & & Low & Intermediate & High \\
\hline \multirow[t]{3}{*}{ Low } & \multirow{3}{*}{$\begin{array}{l}\text { Flexible cystoscopy } \\
\text { Ureteral catheterization } \\
\text { Ureteroscopy }\end{array}$} & ASA & Continue & Continue & Continue \\
\hline & & $\begin{array}{l}\mathrm{P}^{\mathrm{P} \mathrm{Y}_{12} \text { receptor }} \\
\quad \text { inhibitors }\end{array}$ & $\begin{array}{l}\text { Discontinue } 5 \text { days before for } \\
\text { clopidogrel/ticagrelor, } 7 \text { days } \\
\text { before for prasugrel } \\
\text { Resume within } 24-72 \mathrm{~h} \\
\text { (with a loading dose) }\end{array}$ & Continue & Continue \\
\hline & & NOAC & Discc & $\begin{array}{l}\text { ontinue: selecting individual cases } \\
\text { tinue at least } 24-48 \mathrm{~h} \text { before surgery } \\
\text { Resume within } 48-72 \mathrm{~h} \neq\end{array}$ & \\
\hline \multirow{3}{*}{ Intermediate } & \multirow{3}{*}{$\begin{array}{l}\text { Prostate biopsy } \\
\text { Orchiectomy } \\
\text { Circumcision }\end{array}$} & ASA & Discontinue & $\begin{array}{l}\text { Elective surgery: postpone } \\
\text { Nondeferrable surgery: continue }\end{array}$ & $\begin{array}{l}\text { Elective surgery: postpone } \\
\text { Nondeferrable surgery: continue }\end{array}$ \\
\hline & & $\begin{array}{l}\mathrm{P} 2 \mathrm{Y}_{12} \text { receptor } \\
\text { inhibitors }\end{array}$ & $\begin{array}{l}\text { Discontinue } 5 \text { days before for } \\
\text { clopidogrel/ticagrelor, } 7 \text { days } \\
\text { before for prasugrel } \\
\text { Resume within } 24-72 \mathrm{~h} \text { (with a } \\
\text { loading dose) }\end{array}$ & $\begin{array}{l}\text { Elective surgery: postpone } \\
\text { Nondeferrable surgery: } \\
\text { - Discontinue } 5 \text { days before for } \\
\text { clopidogrel/ticagrelor, } 7 \text { days } \\
\text { before for prasugrel } \\
\text { - Resume within } 24-72 \text { h* (with } \\
\text { a loading dose) }\end{array}$ & $\begin{array}{l}\text { Elective surgery: postpone } \\
\text { Nondeferrable surgery: } \\
\text { - Discontinue } 5 \text { days before } \\
\text { for clopidogrel/ticagrelor, } \\
7 \text { days before for prasugrel } \\
\text { - Resume within 24-72 h* } \\
\text { (with a loading dose) } \\
\text { Consider bridge therapy* }\end{array}$ \\
\hline & & NOAC & \multicolumn{3}{|c|}{$\begin{array}{l}\text { Discontinue at least } 24-96 \mathrm{~h} \text { before surgery } \dagger \\
\text { Resume within } 48-72 \mathrm{~h} \neq\end{array}$} \\
\hline \multirow[t]{3}{*}{ High } & \multirow{3}{*}{$\begin{array}{l}\text { Radical and partial } \\
\text { nephrectomy } \\
\text { Percutaneous } \\
\text { nephrostomy } \\
\text { Percutaneous lithotripsy } \\
\text { Radical cystectomy } \\
\text { Prostatectomy } \\
\text { Endoscopic resection of } \\
\text { prostate/endoscopic } \\
\text { bladder surgery } \\
\text { Penectomy } \\
\text { Partial orchiectomy }\end{array}$} & ASA & Discontinue & $\begin{array}{l}\text { Elective surgery: postpone } \\
\text { Nondeferrable surgery: } \\
\text { discontinue }\end{array}$ & $\begin{array}{l}\text { Elective surgery: postpone } \\
\text { Nondeferrable surgery: continue }\end{array}$ \\
\hline & & $\begin{array}{l}\mathrm{P} 2 \mathrm{Y}_{12} \text { receptor } \\
\text { inhibitors }\end{array}$ & $\begin{array}{l}\text { Discontinue } 5 \text { days before for } \\
\text { clopidogrel/ticagrelor, } 7 \text { days } \\
\text { before for prasugrel } \\
\text { Resume within } 24-72 \mathrm{~h} \text { (with a } \\
\text { loading dose) }\end{array}$ & $\begin{array}{l}\text { Elective surgery: postpone } \\
\text { Nondeferrable surgery: } \\
\text { - Discontinue } 5 \text { days before for } \\
\text { clopidogrel/ticagrelor, } 7 \text { days } \\
\text { before for prasugrel } \\
\text { - Resume within } 24-72 \mathrm{~h} \text { * (with } \\
\text { a loading dose) }\end{array}$ & $\begin{array}{l}\text { Elective surgery: postpone } \\
\text { Nondeferrable surgery: } \\
\text { - Discontinue } 5 \text { days before } \\
\text { for clopidogrel/ticagrelor, } \\
7 \text { days before for prasugrel } \\
\text { - Resume within 24-72 h* } \\
\text { (with a loading dose) } \\
\text { Consider bridge therapy* }\end{array}$ \\
\hline & & NOAC & \multicolumn{3}{|c|}{$\begin{array}{l}\text { Discontinue at least } 48-96 \mathrm{~h} \text { before surgery } \dagger \\
\text { Resume within } 48-72 \mathrm{~h} \neq\end{array}$} \\
\hline
\end{tabular}

recently approved for secondary prevention in adjunct to standard antiplatelet therapy with aspirin and a $\mathrm{P}_{2} \mathrm{Y}_{12}$ inhibitor in patients with prior MI or peripheral vascular disease, was not associated with increased perioperative ischemic or bleeding events in patients undergoing NCS (54).

The offset of effects of $\mathrm{P}_{2} \mathrm{Y}_{12}$ inhibiting therapy are subject to variability and may be accelerated in patients with high platelet turnover states such as a recent acute coronary event or in patients with diabetes. The offset of effects of $\mathrm{P}_{2} \mathrm{Y}_{12}$ inhibiting therapy are not known to be affected by renal function. Although the timing of offset of oral $\mathrm{P}_{2} \mathrm{Y}_{12}$ inhibitory effects is subject to interindividual variability, which may be monitored by platelet function tests, there is limited data support their routine use to define timing of surgery. However, platelet function monitoring may be considered in selected cases. Bridging with an intravenous antiplatelet agent is usually reserved for patients deemed at high thrombotic risk (who cannot safely interrupt oral antiplatelet therapy) undergoing nondeferrable surgery at high risk of bleeding. In case of reduced enteral absorption, as for gastric or intestinal resections, bridging with intravenous antiplatelet therapy may be considered in the perioperative period. Intravenous aspirin, if available, may also be considered in these subjects.

URGENT SURGERY. Urgent surgery is defined as surgery required within $48 \mathrm{~h}$. Surgery should be delayed as long as possible in stented patients on DAPT. When a surgical procedure is required in a patient on DAPT, a careful evaluation of the timing of surgery should be made together with surgeons and anesthesiologists and risk and benefits should be considered. In case of urgent surgical procedures considered at high hemorrhagic risk, antiplatelet therapy should be immediately discontinued and all potential 
perioperative supportive measures should be implemented in case of excess of bleeding. There are no commercially available antidotes for antiplatelet agents. Restoration of platelet function can be achieved with platelet transfusions. However, there is no consensus on threshold levels of platelet aggregation as well as number of units of platelets to be transfused to prevent a bleeding event in patients undergoing urgent surgery or in patients experiencing a bleeding event. Ideally, platelet transfusions should be given after the oral antiplatelet agent is no longer in circulation to avoid that the newly transfused platelets be inhibited. Aspirin has a very short halflife ( $\sim 15$ to $20 \mathrm{~min}$ ). The oral $\mathrm{P}_{2} \mathrm{Y}_{12}$ receptor inhibitors have longer half-lives than aspirin. In particular, the active metabolites of thienopyridines are detectable in circulation for up to $6 \mathrm{~h}$ (longer for prasugrel than clopidogrel). The half-life of ticagrelor and its major metabolite is approximately 10 to $12 \mathrm{~h}$. Therefore, platelet transfusions should be avoided within 4 to $6 \mathrm{~h}$ after the last dose of a thienopyridine and 10 to $12 \mathrm{~h}$ after last dosing of ticagrelor.

WHEN TO RESTART ORAL ANTIPLATELET THERAPY. If aspirin has been interrupted, this should be initiated immediately after surgery. Once successful hemostasis has been obtained, oral $\mathrm{P}_{2} \mathrm{Y}_{12}$ inhibitors should be resumed within 24 to $48 \mathrm{~h}$ after surgery using a loading dose (47). In particular, in patients at increased bleeding risk, clopidogrel should be preferred over prasugrel or ticagrelor. In general, clopidogrel should be resumed with a 600-mg rather than a 300-mg loading dose. However, resumption of antiplatelet drugs after surgery may be deferred in case of clinically relevant bleeding complications.

\section{MANAGEMENT OF OAC THERAPY IN PATIENTS WITH ATRIAL FIBRILLATION UNDERGOING SURGERY}

Because of the growing prevalence of stented patients with AF who may be concomitantly treated with antiplatelet therapy and OAC therapy, the Writing Committee of this document agreed on the importance of addressing the perioperative management of antithrombotic therapy, in particular NOACs, in these patients. However, the Writing Committee believed that the perioperative management of OAC therapy in patients with prosthetic valves or indications different from AF should not be discussed given the very limited information on these patients.

As for antiplatelet agents, the perioperative management of OAC therapy should also be based on the ischemic risk of the patient and hemorrhagic risk related to the specific surgical or endoscopic procedure. Given the long and variable half-life of vitamin $\mathrm{K}$ antagonists (VKAs), guidelines recommend that patients discontinue treatment 5 days before major procedures (55). Notably, the optimal timing for surgery after discontinuation of warfarin therapy should be based on international normalized ratio values. If there is a need for surgery or a procedure where the international normalized ratio is still elevated $(>1.5)$, the administration of low-dose oral vitamin $\mathrm{K}$ to normalize the international normalized ratio may be considered. VKAs should be resumed on day 1 or 2 after surgery, depending on adequate hemostasis (11).

The more predictable anticoagulant effect and shorter half-life of NOACs compared with VKA have the potential to simplify the perioperative management of OAC therapy $(56,57)$, particularly if a standard hemorrhagic stratification of the types of surgical and endoscopic procedures is available.

However, the lack of a widely available test to precisely measure the anticoagulant effect of NOACs (58) have raised concerns that NOACs may increase the risk of bleeding complications related to surgery or invasive procedures, particularly if performed on an emergency basis (5).

In the European Heart Rhythm Association Practical Guide on the use of NOAC, procedural hemorrhagic risk has been defined according to the frequency of bleeding and its impact (56). However, perioperative bleeding risk should be also defined according to the availability of an effective mechanical hemostasis. Therefore, in SAS 2 some procedures (e.g., prostate biopsy) have been classified by surgeons at a higher bleeding risk, due to the difficulties of achieving an adequate mechanical hemostasis in case of bleeding (Table 6). Owing to their relatively short half-life (especially in patients with normal renal function), NOACs can be safely discontinued for a short period in the perioperative phase. For this reason, consistent with the guidelines (56), a standard approach has been suggested based on hemorrhagic risk (Tables 3 to 6, Online Tables 1 to 11).

Assessment of drug exposure and anticoagulant effect may be needed in emergency situations, such as a serious bleeding and thrombotic events, need for urgent surgery, or in special clinical situations such as patients who present with renal or hepatic insufficiency, potential drug-drug interactions or suspected overdosing (59). It should be emphasized that an individual assessment of the thrombotic and hemorrhagic risk should be always performed and in very high-risk patients (i.e., patients with congenital coagulopathies), a hematological evaluation should be provided. 


\section{BRIDGING ANTICOAGULANT THERAPY}

Recent data showed that, in patients with $\mathrm{AF}$ who require perioperative interruption of warfarin treatment for an elective procedure, a strategy of discontinuing warfarin treatment without the use of bridging anticoagulation was noninferior to the use of bridging anticoagulation for the prevention of arterial thromboembolism (60). In addition, bridging conferred a risk of major bleeding that was nearly triple the risk associated with no bridging. Considering that NOACs have predictable pharmacokinetics, short half-lives and rapid onset or offset of action, bridging anticoagulant therapy is not routinely recommended in NOAC-treated patients during treatment interruption for elective surgery $(56,61)$.

In patients in whom resumption of full dose anticoagulation after surgery may carry a bleeding risk that could outweigh the risk of cardioembolism, especially if associated with prolonged immobilization, an initial anticoagulant therapy with venous-prophylactic doses of unfractionated heparin, low molecular weight heparin, or NOACs should be considered (62). Bridge therapy with parental anticoagulation may also be considered for patients in whom intake of oral medications (including NOACs) is not possible (e.g., post-operative ileus) in the immediate post-operative phase. In these settings, NOAC therapy should always be resumed when the infusion of unfractionated heparin is discontinued or after $12 \mathrm{~h}$ from the last dose of subcutaneous low-molecular-weight heparin (63).

SURGERY AFTER STENTING:

PRACTICAL RECOMMENDATIONS FOR

PERIOPERATIVE MANAGEMENT OF NOACS

The perioperative management of NOACs should take into consideration 3 key factors: 1) the hemorrhagic risk of the surgery; 2) the clinical characteristics of the patient (e.g., age, history of previous thrombosis or bleeding, renal and liver function, concomitant medications); and 3) the specific NOAC used. Summary recommendations are provided in Tables 3 to 6 and Online Tables 1 to 11 (Stent and Surgery app; https://itunes.apple.com/us/app/stentsurgery/id551350096? $\mathrm{mt}=8$ ).

ELECTIVE SURGERY. In patients treated with an antifactor Xa agent (rivaroxaban, apixaban, edoxaban) undergoing surgical interventions classified at low risk of bleeding, $24 \mathrm{~h}$ of withdrawal might be sufficient if creatinine clearance $(\mathrm{CrCl})$ calculated with Cockroft-Gault formula is $>30 \mathrm{ml} / \mathrm{min}$. In case of severe renal impairment ( $\mathrm{CrCl} 15$ to $30 \mathrm{ml} / \mathrm{min})$, the anti-factor Xa agent should be discontinued for at least $36 \mathrm{~h}$. Dabigatran requires at least $24 \mathrm{~h}$ of withdrawal if the $\mathrm{CrCl}$ is $>80 \mathrm{ml} / \mathrm{min}$, but should be discontinued at least 36 and $48 \mathrm{~h}$ in case of $\mathrm{CrCl} 50$ to 80 $\mathrm{ml} / \mathrm{min}$ and $<50 \mathrm{ml} / \mathrm{min}$, respectively $(56,63)$.

In patients at intermediate to high risk of hemorrhagic complications, a more cautious approach is recommended, suggesting a prolonged withdrawal of the anti-factor $\mathrm{Xa}$ agent $(\geq 24$ for intermediate and $\geq 48 \mathrm{~h}$ for high bleeding risk) in all cases. In dabigatran-treated patients, therapy should be discontinued at least $48 \mathrm{~h}$ before surgery if $\mathrm{CrCl}$ is $>80$ $\mathrm{ml} / \mathrm{min}$, at least $72 \mathrm{~h}$ if $\mathrm{CrCl}$ is 50 to $80 \mathrm{ml} / \mathrm{min}$, and at least $96 \mathrm{~h}$ if $\mathrm{CrCl}$ is $<50 \mathrm{ml} / \mathrm{min}(56,62)$.

In patients treated with very low-dose rivaroxaban (2.5 mg twice daily) on top of DAPT, rivaroxaban can be safely discontinued $\geq 48 \mathrm{~h}$ before surgical interventions (independent of the bleeding risk) (64).

URGENT SURGERY. In NOAC-treated patients, surgery should be delayed as long as possible and for at least for 1 to 2 elimination half-lives of the drug, when clinically acceptable (56). In a post hoc analysis of the RE-LY (Randomized Evaluation of Long-Term Anticoagulation Therapy) trial, in patients requiring urgent surgery the rate of bleeding was similar in the dabigatran and warfarin subgroups (65). If surgery cannot be deferred, NOACs should be immediately discontinued and all potential perioperative supportive measures should be implemented in case of excess of bleeding (e.g., selective blood vessel cautery, intravenous fluid injection, red blood cell transfusion and platelet transfusion) (66). In selected cases, a reversal of the anticoagulant effect may be considered using coagulation factor concentrates (e.g., prothrombin complex concentrate). Idarucizumab, a humanized antibody fragment that specifically inhibits dabigatran, was recently approved for use in case of major bleeding complications or before urgent surgical interventions in patients on chronic treatment with dabigatran. Idarucizumab completely reversed the anticoagulant effect of dabigatran within minutes in a cohort of patients who had serious bleeding or required an urgent procedure included in the $\mathrm{RE}$ VERSE AD (Reversal Effects of Idarucizumab on Active Dabigatran) trial (58). Andexanet alfa (andexanet) is a recombinant modified human factor $\mathrm{Xa}$ decoy protein (not commercially available) that has been shown to reverse the inhibition of factor Xa in healthy volunteers. Andexanet showed to reduce antifactor Xa activity in patients with acute major bleeding associated with factor Xa inhibitors, with effective hemostasis occurring in the majority of the patient population from the ANNEXA-4 (Andexanet Alfa in 
Patients Receiving a Factor Xa Inhibitor Who Have Acute Major Bleeding) trial (67). However, the only available evidence on patients requiring urgent surgery derives from the cohort of 202 patients enrolled in the RE-VERSE-AD trial (58) and that additional evidence is warranted to better support the safety of this approach. In emergent situations, measurement of the anticoagulant effect of NOACs to guide medical therapy and surgical timing may be considered (61).

WHEN TO RESTART NOAC THERAPY. NOACS should be restarted as soon as possible, once adequate hemostasis has been achieved. A careful evaluation of the ischemic and hemorrhagic risk should be provided in each patient. Standard doses are recommended to achieve complete anticoagulation. Although the use of lower doses of NOAC therapy have been suggested to reduce the risk of bleeding, it is unknown whether they are effective or safe and this strategy is currently not recommended (57).

\section{CONCLUSIONS}

The SAS 2 document derives from a multidisciplinary collaboration between cardiologists, anesthesiologists, hematologists, and surgeons, which provides practical recommendations on the perioperative management of antithrombotic therapy (antiplatelet and anticoagulant) in patients treated with coronary stents. The approach to the perioperative management of antithrombotic therapy in these patients is defined based on the predicted individual risk of thrombotic complications against the anticipated risk of surgical bleeding complications. Overall, aspirin can be maintained in the vast majority of surgical and endoscopic procedures, whereas recommendations about $\mathrm{P}_{2} \mathrm{Y}_{12}$ inhibitors are more heterogeneous and the indications for bridging with an intravenous antiplatelet agent reserved for patients deemed at high thrombotic risk who cannot safely interrupt oral antiplatelet therapy. NOACs can be perioperatively discontinued without need for bridging therapy in most procedures; the use of unfractionated or low-molecular-weight heparin is not routinely recommended, unless administered as prophylaxis for venous thromboembolism. The recommendations from this document derive mostly from expert opinions, underscoring the need for dedicated research in this field.

ADDRESS FOR CORRESPONDENCE: Dr. Roberta Rossini, Dipartimento Emergenza e Aree Critiche, Ospedale Santa Croce e Carle, via Michele Coppino 26, Cuneo 12100, Italy. E-mail: roberta.rossini2@gmail.com.

\section{REFERENCES}

1. Benjamin EJ, Blaha MJ, Chiuve $S E$, et al., American Heart Association Statistics Committee and Stroke Statistics Subcommittee. Heart Disease and Stroke Statistics-2017 Update: a report from the American Heart Association. Circulation 2017; 135:e146-603.

2. Moschovitis A, Cook S, Meier B. Percutaneous coronary interventions in Europe in 2006. EuroIntervention 2010;6:189-94.

3. Brilakis ES, Banerjee $S$, Berger PB. Perioperative management of patients with coronary stents. J Am Coll Cardiol 2007;49:2145-50.

4. Capodanno D, Angiolillo DJ. Management of antiplatelet therapy in patients with coronary artery disease requiring cardiac and noncardiac surgery. Circulation 2013;128:2785-98.

5. Douketis J, Berger PB, Dunn AS, et al. The perioperative management of antithrombotic therapy: American College of Chest Physicians Evidence-Based Clinical Practice Guidelines (8th Edition). Chest 2008;133:299-339.

6. Douketis JD, Spyropoulos AC, Spencer FA et al., American College of Chest Physicians. Perioperative management of antithrombotic therapy: Antithrombotic Therapy and Prevention of Thrombosis, 9th ed: American College of Chest Physicians Evidence-Based Clinical Practice Guidelines. Chest 2012;141:e326-50.
7. Schouten O, van Domburg RT, Bax JJ, et al. Noncardiac surgery after coronary stenting: early surgery and interruption of antiplatelet therapy are associated with an increase in major adverse cardiac events. J Am Coll Cardiol 2007;49:122-4.

8. Albaladejo $P$, Marret E, Samama CM, et al. Noncardiac surgery in patients with coronary stents: the RECO study. Heart 2011;97:1566-72.

9. Rossini R, Musumeci G, Capodanno $D$, et at. Perioperative management of oral antiplatelet therapy and clinical outcomes in coronary stent patients undergoing surgery. Results of a multicentre registry. Thromb Haemost 2015;113:272-82.

10. Valgimigli $M$, Bueno $H$, Byrne RA, et al. 2017 ESC focused update on dual antiplatelet therapy in coronary artery disease developed in collaboration with EACTS: The Task Force for dual antiplatele therapy in coronary artery disease of the European Society of Cardiology (ESC) and of the European Association for Cardio-Thoracic Surgery (EACTS). Eur Heart J 2018;39:213-60.

11. Kristensen SD, Knuuti J, Saraste A, et al. 2014 ESC/ESA guidelines on non-cardiac surgery: cardiovascular assessment and management: the Joint Task Force on non-cardiac surgery: cardiovascular assessment and management of the European Society of Cardiology (ESC) and the European Society of Anaesthesiology (ESA). Eur Heart J 2014:35:2383-431.
12. Levine GN, Bates ER, Bittl JA, et al. 2016 ACC/ AHA guideline focused update on duration of dual antiplatelet therapy in patients with coronary artery disease: a report of the American College of Cardiology/American Heart Association Task Force on Clinical Practice Guidelines. J Am Coll Cardiol 2016;68:1082-115.

13. Rossini R, Musumeci G, Visconti LO, et al. Italian Society of Invasive Cardiology (SICI-GISE), Italian Association of Hospital Cardiologists (ANMCO), Italian Society for Cardiac Surgery (SICCH), Italian Society of Vascular and Endovascular Surgery (SICVE), Italian Association of Hospital Surgeons (ACOI), Italian Society of Surgery (SIC), Italian Society of Anaesthesia and Intensive Care Medicine (SIAARTI), Lombard Society of Surgery (SLC), Italian Society of Maxillofacial Surgery (SICMF), Italian Society of Reconstructive Plastic Surgery and Aesthetics (SICPRE), Italian Society of Thoracic Surgeons (SICT), Italian Society of Urology (SIU), Italian Society of Orthopaedics and Traumatology (SIOT), Italian Society of Periodontology (SIdP), Italian Federation of Scientific Societies of Digestive System Diseases Lombardia (FISMAD), Association of Obstetricians Gynaecologists Italian Hospital Lombardia (AOGOI), Society of Ophthalmology Lombardia (SOL). Perioperative management of antiplatelet therapy in patients with coronary stents undergoing cardiac and noncardiac surgery: A consensus document from 
Italian cardiological, surgical and anaesthesiological societies. Eurolntervention 2014;10:38-46.

14. Rossini R, Angiolillo DJ, Musumeci $M$, et al. Antiplatelet therapy and outcome in patients undergoing surgery following coronary stenting: results of the Surgery After Stenting Registry. Catheter Cardiovasc Intv 2017;89:E13-25.

15. Bittl JA, Baber U, Bradley SM, Wijeysundera DN. Duration of dual antiplatelet therapy: A systematic review for the 2016 ACC AHA guideline focused update on duration of dual antiplatelet therapy in patients with coronary artery disease: a report of the American College of Cardiology/American Heart Association Task Force on Clinical Practice Guidelines. Circulation 2016; 134:e156-78.

16. Windecker $S$, Kolh $P$, Alfonso $F$, et al., Task Force on Myocardial Revascularization of the European Society of Cardiology (ESC) and the European Association or Cardio-Thoracic Surgery (EACTS) Developed with the special contribution of the European Association of Percutaneous Cardiovascular Interventions (EAPCI). 2014 ESC/ EACTS Guidelines on myocardial revascularization. Eur Heart J 2014;35. 2541-19.

17. Rajagopalan S, Ford I, Bachoo P, et al. Platelet activation, myocardial ischemic events and postoperative non-response to aspirin in patients undergoing major vascular surgery. J Thromb Haemost 2007:5:2028-35.

18. Banerjee $S$, Angiolillo DJ, Boden WE, et al. Use of antiplatelet therapy/DAPT for post-PCI patients undergoing noncardiac surgery. J Am Coll Cardiol 2017;69:1861-70.

19. Saia F, Belotti LM, Guastaroba P, et al. Risk of adverse cardiac and bleeding events following cardiac and noncardiac surgery in patients with coronary stent: how important is the interplay between stent type and time from stenting to surgery? Circ Cardiovasc Qual Outcomes 2016;9: 39-47.

20. Stone GW, Gao R, Kimura T, et al. 1-year outcomes with the Absorb bioresorbable scaffold in patients with coronary artery disease: a patientlevel, pooled meta-analysis. Lancet 2016;387: 1277-89.

21. Capodanno D, Angiolillo DJ. Antiplatelet therapy after implantation of bioresorbable vascular scaffolds: a review of the published data, practical recommendations, and future directions. J Am Coll Cardiol Intv 2017;10:425-37.

22. Hawn MT, Graham LA, Richman JR, et al. The incidence and timing of non cardiac surgery after cardiac stent implantation. J Am Coll Surg 2012; 214:658-66.

23. Egholm $G$, Kristensen SD, Thim $T$, et al. Risk associated with surgery within 12 months after coronary drug-eluting stent implantation. J Am Coll Cardiol 2016:68:2622-32.

24. Mahmoud KD, Sanon $S$, Habermann EB, et al. Perioperative cardiovascular risk of prior coronary stent implantation among patients undergoing noncardiac surgery. J Am Coll Cardiol 2016;67: 1038-49.

25. Mehran R, Baber U, Steg PG, et al. Cessation of dual antiplatelet treatment and cardiac events after percutaneous coronary intervention (PARIS):
2 year results from a prospective observational study. Lancet 2013:382:1714-22.

26. Nuttall GA, Brown MJ, Stombaugh JW, et al. Time and cardiac risk of surgery after bare-metal stent percutaneous coronary intervention. Anesthesiology 2008;109:588-95.

27. Wilson $\mathrm{SH}$, Fasseas $\mathrm{P}$, Orford JL, et al. Clinical outcome of patients undergoing non-cardiac surgery in the 2 months following coronary stenting. J Am Coll Cardiol 2003;42:234-40.

28. Kaluza GL, Joseph J, Lee JR, et al. Catastrophi outcomes of noncardiac surgery soon after coronary stenting. J Am Coll Cardiol 2000;35: 1288-94.

29. Cruden NL, Harding $S A$, Flapan $A D$, et al. Previous coronary stent implantation and cardiac events in patients undergoing noncardiac surgery. Circ Cardiovasc Interv 2010;3:236-42.

30. Tokushige A, Shiomi $H$, Morimoto $T$, et al., CREDO-Kyoto PCI/CABG registry cohort-2 investigators. Incidence and outcome of surgical procedures after coronary bare-metal and drugeluting stent implantation: a report from the CREDO-Kyoto PCI/CABG registry cohort-2. Circ Cardiovasc Interv 2012;5:237-46.

31. Holmes DR Jr., Kereiakes DJ, Garg S, et al. Stent thrombosis. J Am Coll Cardiol 2010;56: 1357-65.

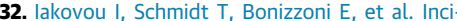
dence, predictors, and outcome of thrombosis after successful implantation of drug-eluting stents. JAMA 2005:293:2126-30.

33. Airoldi F, Colombo A, Morici N, Latib A, et al. Incidence and predictors of drug-eluting stent thrombosis during and after discontinuation of thienopyridine treatment. Circulation 2007;116: 745-54.

34. Giustino $G$, Chieffo A, Palmerini $T$, et al. Efficacy and safety of dual antiplatelet therapy after complex PCI. J Am Coll Cardiol 2016;68:1851-64.

35. Bhatt $D L$, Eagle $K A$, Ohman EM, et al., REACH Registry Investigators. Comparative determinants of 4-year cardiovascular event rates in stable outpatients at risk of or with atherothrombosis. JAMA 2010;304:1350-7.

36. Holcomb CN, Graham LA, Richman JS, et al. The incremental risk of coronary stents on postoperative adverse events: a matched cohort study. Ann Surg 2016;263:924-30.

37. Garg S, Sarno G, Garcia-Garcia HM, et al. ARTS-II Investigators. A new tool for the risk stratification of patients with complex coronary artery disease: the Clinical SYNTAX Score. Circ Cardiovasc Interv 2010;3:317-26.

38. Parasca CA, Head $S J$, Milojevic $M$, et al. SYNTAX Investigators. Incidence, characteristics, predictors, and outcomes of repeat revascularization after percutaneous coronary intervention and coronary artery bypass grafting: the SYNTAX trial at 5 years. J Am Coll Cardiol Intv 2016;9: 2493-507.

39. Généreux $P$, Palmerini $T$, Caixeta $A$, et al. Quantification and impact of untreated coronary artery disease after percutaneous coronary intervention: the residual SYNTAX (Synergy Between
PCl with Taxus and Cardiac Surgery) score. J Am Coll Cardiol 2012:59:2165-74.

40. Huber KC, Evans MA, Bresnahan JF, et al. Outcome of non cardiac operations in patients with severe coronary-artery disease successfully treated pre-operatively with coronary angioplasty. Mayo Clin Proc 1992;67:15-21.

41. Wijeysundera DN, Wijeysundera HC, Yun $L$, et al. Risk of elective major non cardiac surgery after coronary stent insertion: a population-based study. Circulation 2012;126:1355-62.

42. Hawn MT, Graham LA, Richman JS, Itani KM, Henderson WG, Maddox TM. Risk of major adverse cardiac events following non cardiac surgery in patients with coronary stents. JAMA 2013;310: 1462-72.

43. Franchi $F$, Rollini $F$, Muñiz-Lozano $A$, Cho JR, Angiolillo DJ. Cangrelor: a review on pharmacology and clinical trial development. Expert Rev Cardiovasc Ther 2013;11:1279-91.

44. Angiolillo DJ, Schneider DJ, Bhatt $D L$, et al. Pharmacodynamic effects of cangrelor and clopidogrel: the platelet function substudy from the cangrelor versus standard therapy to achieve optimal management of platelet inhibition (CHAMPION) trials. J Thromb Thrombolysis 2012;34:44-55.

45. Bhatt $D L$, Stone GW, Mahaffey $K W$, et al., CHAMPION PHOENIX Investigators. Effect of platelet inhibition with cangrelor during $\mathrm{PCI}$ on ischemic events. N Engl J Med 2013;368:1303-13.

46. Angiolillo DJ, Firstenberg MS, Price MJ, et al. Bridging antiplatelet therapy with cangrelor un patients undergoing cardiac surgery. A randomized control trial. JAMA 2012;307:265-74.

47. Angiolillo DJ, Rollini F, Storey RF, et al. International expert consensus on switching platelet P2Y12 receptor-inhibiting therapies. Circulation 2017;136:1955-75.

48. Savonitto S, Caracciolo M, Cattaneo M, De Servi S. Management of patients with recently implanted coronary stents on dual antiplatelet therapy who need to undergo major surgery. J Thromb Haemost 2011; 9:2133-42.

49. Pickett AM, Taylor DA, Ackman ML. Prolonged infusion of eptifibatide as bridge therapy between bare-metal stent insertion and cardiovascula surgery: case report and review of the literature. Pharmacotherapy 2010;30:127-133e.

50. Devereaux PJ, Mrkobrada M, Sessler DI, et al. POISE-2 Investigators. Aspirin in patients undergoing noncardiac surgery. N Engl J Med 2014;370: 1494-503.

51. Graham MM, Sessler DI, Parlow JL, et al. Aspirin in patients with previous percutaneous coronary intervention undergoing noncardiac surgery. Ann Intern Med 2018;168:237-44.

52. Hansson EC, Jidéus $L$, Åberg $B$, et al. Coronary artery bypass grafting-related bleeding complications in patients treated with ticagrelor or clopidogrel: a nationwide study. Eur Heart J 2016;37; 189-97.

53. Gherli R, Mariscalco G, Dalén M, et al. Safety of preoperative use of ticagrelor with or without aspirin compared with aspirin alone in patients with acute coronary syndromes undergoing 
coronary artery bypass grafting. JAMA Cardiol 2016;1:921-8.

54. van Diepen $S$, Tricoci $P$, Podder $M$, et al. Efficacy and safety of vorapaxar in non-ST-segment elevation acute coronary syndrome patients undergoing noncardiac surgery. J Am Heart Assoc 2015;4:e002546.

55. European Heart Rhythm Association, European Association for Cardio-Thoracic Surgery, Camm AJ et al. Guidelines for the management of atria fibrillation: the Task Force for the Management of Atrial Fibrillation of the European Society of Cardiology (ESC). Eur Heart J 2010;31:2369-429. Erratum in: Eur Heart J 2011:32:1172.

56. Heidbuchel $H$, Verhamme $P$, Alings $M$, et al. Updated European Heart Rhythm Association Prac tical Guide on the use of non-vitamin K antagonis anticoagulants in patients with non-valvular atria fibrillation. Europace 2015;17:1467-507.

57. Schulman S, Crowther MA. How I treat with anticoagulants in 2012: new and old anticoagu lants, and when and how to switch. Blood 2012; 119:3016-23.

58. Pollack CV Jr., Reilly PA, van Ryn J, et al. Idarucizumab for dabigatran reversal - full cohort analysis. N Engl J Med 2017;377:431-41.

59. Lip GY, Windecker S, Huber K, et al. Management of antithrombotic therapy in atrial fibrillation patients presenting with acute coronary syndrome or undergoing percutaneous coronary or valve interventions: a joint consensus document of the European Society of Cardiology Working Group on
Thrombosis, European Heart Rhythm Association (EHRA), European Association of Percutaneous Cardiovascular Interventions (EAPCI) and European Association of Acute Cardiac Care (ACCA) endorsed by the Heart Rhythm Society (HRS) and Asia-Pacific Heart Rhythm Society (APHRS). Eur Heart J 2014;35:3155-79.

60. Douketis JD, Spyropoulos AC, Kaatz S, et al. BRIDGE Investigators. Perioperative bridging anticoagulation in patients with atrial fibrillation. N Engl J Med 2015:373:823-33.

61. Spyropoulos AC, Bauersachs RM, Omran H Cohen M. Periprocedural bridging therapy in $\mathrm{pa}-$ tients receiving chronic oral anticoagulation therapy. Curr Med Res Opin 2006;22:1109-22.

62. Sié $P$, Samama CM, Godier $A$, et al., French Study Group on Thrombosis and Haemostasis. Surgery and invasive procedures in patients on long-term treatment with direct oral anticoagu lants: thrombin or factor-Xa inhibitors. Recommendations of the Working Group on Perioperative Haemostasis and the French Study Group on Thrombosis and Haemostasis. Arch Cardiovasc Dis 2011;104:669-76.

63. Bell BR, Spyropoulos AC, Douketis JD. Peri operative management of the direct oral antico agulants: a case-based review. Hematol Oncol Clin North Am 2016;30:1073-84.

64. Mega $J L$, Braunwald $E$, Wiviott $S D$, et al. ATLAS ACS 2-TIMI 51 Investigators. Rivaroxaban in patients with a recent acute coronary syndrome. N Engl J Med 2012;366:9-19.
65. Healey JS, Eikelboom J, Douketis J, et al., RELY Investigators. Periprocedural bleeding and thromboembolic events with dabigatran compared with warfarin: results from the Randomized Evaluation of Long-Term Anticoagulation Therapy (RE-LY) randomized trial. Circulation 2012;126: 343-8.

66. Siegal DM. Managing target-specific oral anticoagulant associated bleeding including an update on pharmacological reversal agents. J Thromb Thrombolysis 2015;39:395-402.

67. Connoly SJ, Milling TJ, Eikelboom JW, et al. Andexanet alfa for acute major bleeding associ ated with factor Xa inhibitors. N Engl Med 2016; 375:1131-41.

KEY WORDS anticoagulant therapy, antiplatelet therapy, atrial fibrillation, bleeding, stent, surgery, thrombosis

APPENDIX For expanded Methods and References sections and supplemental tables, please see the online version of this paper. the CME/MOC quiz for this article. 